Research Article

\title{
On the use of paper to facilitate recyclability of suspension packaging
}

\author{
W. Nica ${ }^{1} \cdot$ J. Roman ${ }^{1} \cdot$ P. Slaets ${ }^{2} \cdot$ M. Juwet ${ }^{1}$ (I)
}

Received: 19 May 2021 / Accepted: 17 September 2021

Published online: 03 October 2021

(c) The Author(s) $2021 \quad$ OPEN

\begin{abstract}
Background of this research is suspension packaging: fragile goods are attached to a panel of cardboard by wrapping it in stretch film. The panel is then appropriately folded, and the whole thing is placed in a cardboard box of corresponding dimensions. The primary objective of this study is to identify paper types that might be used in future as a more sustainable alternative for stretch wrap film. The experimental methods that are utilized are basically variants of mechanical pulling tests on paper samples. Sample preparation and sample size are adopted from international standards, but displacement control is adopted to detect relevant stretchability properties. Some kraft papers show a high ultimate tensile stress and a moderate stretchability, mainly permanent stretch as expected. Although the ultimate tensile stress of paper from recycled fibers is lower, some of these paper grades show a considerable higher stretchability including a higher elastic stretch. It is concluded that both kraft paper and paper grades from recycled fibers may be applicable as a wrapping material for suspension packaging. Further experimental research is needed to identify appropriate wrapping parameters for each paper type.
\end{abstract}

Keywords Paper mechanical properties · Recyclable packaging · Suspension packaging $\cdot$ Horizontal stretch wrapping

\section{Introduction}

Many e-commerce goods need to be packaged prior to shipment to protect the goods during handling and transportation [1-8]. Often a corrugated cardboard box is used in which the goods are placed. Filling material is placed in the empty space around it, which prevents or limits movement in the corrugated box. Filling materials are PE bags filled with air, polystyrene flakes, crumpled paper, cardboard folded into a hollow form, etc. (examples shown in Fig. 1).

This widely used technique is characterized by many disadvantages:

- Many filling materials (such as polystyrene flakes or PE bags filled with air) are not very environmentally
[9-15] friendly, at least in the perception of the end customer.

- Crumpled paper as a filling material is not very suitable for absorbing repeated large impacts.

- The cushioning materials must be applied to all six sides of the product. Even if this is done properly, the filling materials may shift during transport. In the final stage of delivery to the end customer, not all sides are then equally well protected.

- $\quad$ This packaging method is not easy to automate.

This is why "suspension packaging" (example shown in Fig. 2) is arousing great interest as a next generation packaging method.

$\triangle$ M. Juwet, marc.juwet@kuleuven.be | ${ }^{1}$ Department of Mechanical Engineering Campus Gent, KU Leuven Science Engineering and Technology Group, Gebroeders Desmetstraat 1, B-9000 Ghent, Belgium. ${ }^{2}$ KU Leuven Campus Groep T, Celestijnenlaan 300 - bus 2420 , 3001 Leuven, Belgium.

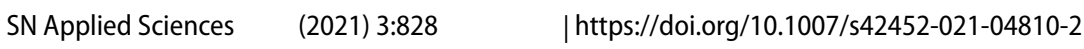


Fig. 1 Examples of void filling in e-commerce packaging
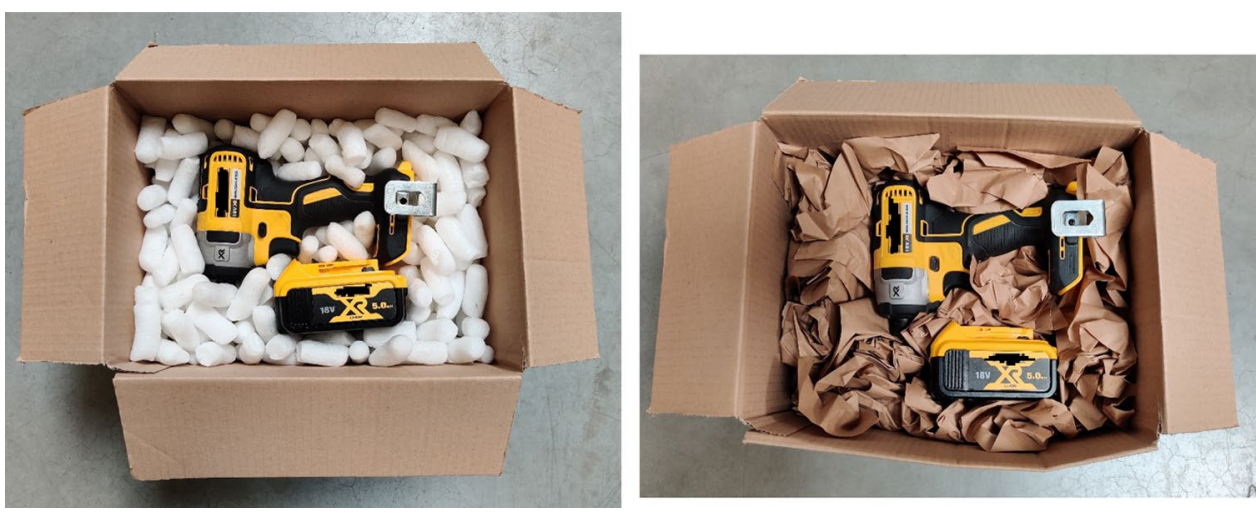

Fig. 2 Example of suspension packaging
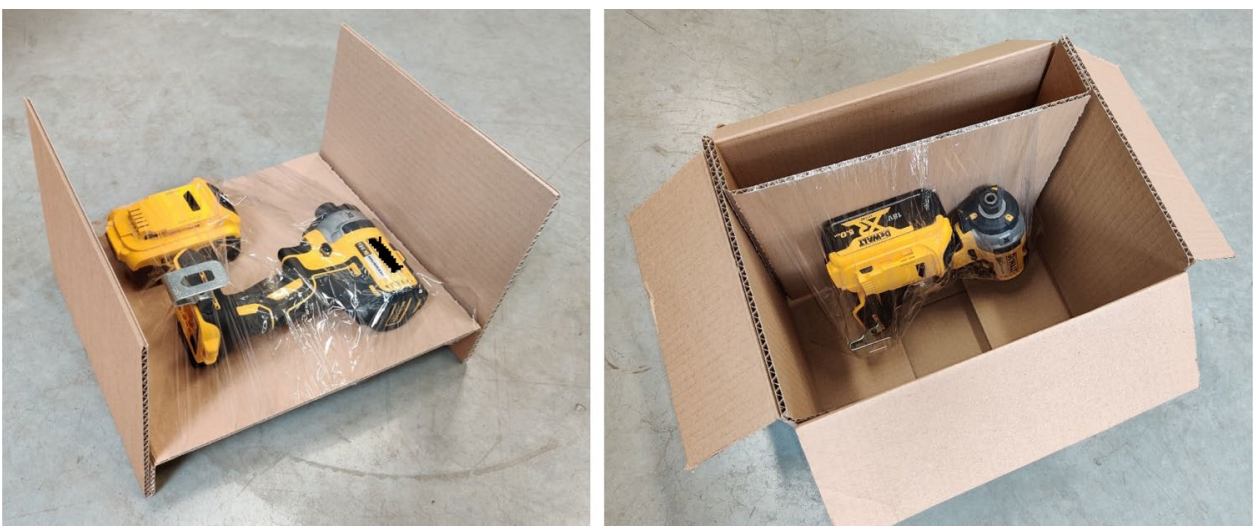

\section{Short description of suspension packaging}

The basis of suspension packaging is a panel of cardboard. Given the desire to keep costs down, most often corrugated cardboard is used. Single or double fluted corrugated board types and all possible flute sizes can be considered. The panel is basically rectangular with the longest side in the machine direction of the corrugated cardboard, i.e., with the flutes parallel to the shortest side of the panel. The width of the panel is about $10 \mathrm{~cm}$ wider than the goods being packed. The goods are stacked on the panel with an uncovered area of about $5 \mathrm{~cm}$ wide on the left and right, and also an uncovered area in front and behind the goods. The length of these uncovered zones is about $20 \mathrm{~cm}$ more than the height of the goods. This allows the uncovered zones of the panel, $5 \mathrm{~cm}$ away from the goods, to be folded in a V-shape: $5 \mathrm{~cm}$ downwards and the rest of the panel upwards. The ascending parts of the $V$ are then in total $10 \mathrm{~cm}$ higher than the goods and ensure that there is an air gap of $5 \mathrm{~cm}$ above and below the goods when the folded panel with the goods is pushed into a box. The inner dimensions of this box must match the outer dimensions of the pleated panel so that the panel cannot move

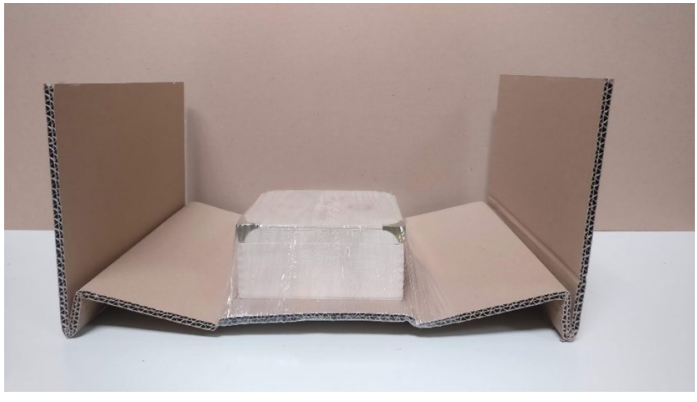

Fig. 3 Insufficient panel stiffness

inside the box. In some cases, illustrated by Fig. 3, the stiffness of a single corrugated cardboard panel is insufficient: the panel bends in the middle and ends up on the bottom of the box, so that shocks are transferred to the goods. This can be prevented by adding an extra strip of corrugated cardboard between the goods and the base panel, preferably with the flute direction perpendicular to the flute direction of the base panel. In extreme cases, extra folds can be provided in the base panel or a honeycomb panel can be used instead of a corrugated panel.

The biggest challenge is to keep the goods in place on the panel during manipulation and transport of the box. 
Classically, the goods are wrapped on the base panel with stretch film, typically $12.5 \mathrm{~cm}$ wide but wider or narrower film can be used as well. During winding, the base panel is supported over a large part of its length by a plate, roller conveyor or another system. The support is interrupted at the point where the film is wrapped to allow the film to be applied to the underside against the base panel (see Fig. 4). After one or a few cylindrical windings, there is a change to screw-type windings and finally to one or a few cylindrical windings. The number of windings required to keep the goods in place depends on the friction between the goods and the base panel on the one hand and the tensile force in the film on the other. In almost all cases, 1 cylindrical winding at the beginning and end of the windings and a screw winding with a pitch of $80 \%$ of the film width are sufficient. At least one side of stretch film has a cling layer. By pre-stretching the film during winding, the resulting tensile force in the film combined with the adhesive layer is sufficient to hold the film in place in relation to the corrugated board and the goods. It is not necessary to glue or fix the film in any other way. The elongation rate of the film during winding is also not very critical. Often a type of film is chosen with a pronounced flat-shaped tensile curve: the tensile force remains almost constant between two limits of elongation, e.g., between 50 and $300 \%$ elongation. If the strain in the film deviates (locally) from the intended value, e.g., at the transition from cylindrical to screw-shaped winding, at protrusions on the goods, at goods that deform during winding, .... this has little influence on the tensile force in the film. All in all, very fast effective winding (typically $3 \mathrm{t} / \mathrm{s}$ ) can be achieved so that the goods remain in place on the base panel.

As demonstrated in [16], well-designed suspension packaging provides as good protection as well-made polystyrene void-fill packaging. The packaging material of suspension packaging is only stretch film and cardboard. In principle, therefore, it is fully recyclable but requires the

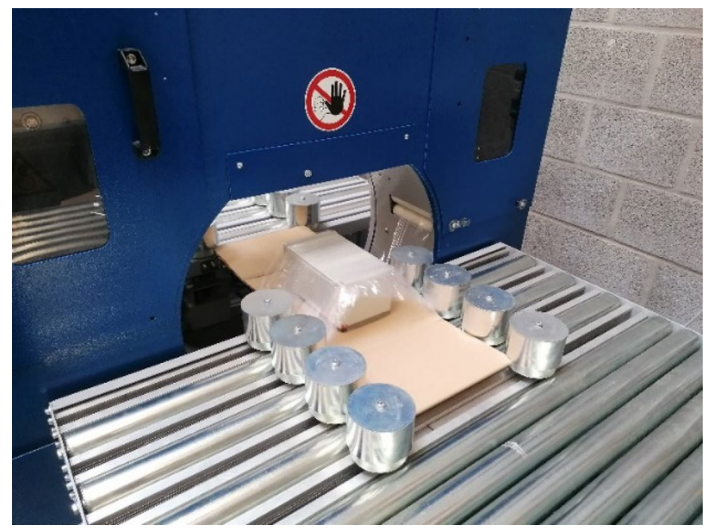

Fig. 4 Stretch wrapping machine cardboard and the wrapping film to be separated. In practice, this does not always happen.

This study investigates whether it would be possible to develop a variant of suspension packaging that uses paper instead of stretch wrap film. Advantages and bottlenecks for wrapping with paper are identified. Possible paper types to avoid or reduce these bottlenecks are identified based on their mechanical properties.

\section{Wrapping paper versus stretch wrap film}

When wrapping paper around the goods on the base panel made of cardboard, the following additional difficulties or bottlenecks arise:

- $\quad$ paper does not have a cling layer so that the beginning and end of the strip of wrapped paper must be held in place by, for example, gluing, staples, adhesive tape, etc. For practical reasons, the beginning and end of the strip of paper are preferably attached to the bottom of the base panel.

- $\quad$ Like most materials, paper is somewhat stretchable [17-22] but much less than stretch film. A wrapping with paper must be designed and applied in such a way that the maximum strain at which the paper tears is not reached anywhere, neither during wrapping nor during manipulations or transport.

- the elastic elongation of paper is only a small fraction of the total elongation [23-25] of paper, so there is a risk that the tensile force in the winding will be lost under shock loading and the goods will shift on the base panel.

- Paper is sensitive to moisture, which means that its tensile strength and elasticity may decrease in a humid environment, unless the paper is water-repellent coated. In view of the ecological reason for this research, only paper types coated with organic material are considered [26-39].

Apart from the ecological advantages, paper as a wrapping material also has some major technical advantages over stretch film:

- if the tensile force varies over a winding, the paper tends to shift slightly under the influence of vibration $[40,41]$, so that the tensile force becomes constant between the starting point and the end point of the strip of paper attached to the base panel. In concrete terms, this means that the average tensile force rather than the instantaneous tensile force needs to be regulated during winding to the extent that the instanta- 
neous tensile force is sufficient to keep the paper in place.

- the stiffness of paper is significantly higher than that of stretch film: for the same weight per surface area, the force required for an equally small extension is a factor of 5 to 10 higher (confirmed by the results of this research presented under paragraph 4.4, more specifically the stretch film (SF) curve in figures 6 and 7 below) with paper than with plastic stretch film or, to put it another way: the strip required for the same tensile force is much narrower with paper than with plastic stretch film.

These advantages must be placed in the context of the wrapping process itself:

1. A narrower strip of wrapping material means that the interruption in the support of the base panel can be shorter. This makes the winding process less susceptible to failure.

2. The narrower the strip of winding material, the easier it is to change direction during winding, e.g., the transition from cylindrical to helical winding and vice versa.

3. If the strap of the winding material pulls the base panel upwards during winding, the tension in the winding material must be limited in order to prevent the base panel from tipping over with the goods. The tensile force in the areas that have been wound with a limited tensile force increases during further manipulations in the case of winding with paper because the tensile force is evenly distributed.

These conceptual considerations lead to the conclusion that paper could be an appropriate winding material, provided the selection of a paper type.

1. With significant stretchability in the longitudinal direction (machine direction).

2. Of which at least part of the stretchability is elastic. This offers the least chance of the goods coming loose from the base panel as a result of impact forces or vibrations.

3. With a high tensile stress. This may be advantageous because fewer windings or windings with narrower strips may suffice.

4. Withstanding tensile forces in combination with smaller transverse forces since this is inevitably the case with directional changes during winding or when winding on erratic shapes.

5. which is sustainably coated or can be coated in a sustainable way so that its mechanical properties are preserved during transport in humid conditions.
The present study, therefore, focuses on the search for papers combining these five mechanical properties [42-47]. Several types of commercially available paper have been collected and tested for this purpose.

\section{Mechanical properties of paper}

\subsection{General}

All types of paper have been conditioned in the same way as far as possible from the moment of arrival at the test laboratory. All test specimens were cut with the same type of knife and stored for at least 1 week in the same room at $20-21^{\circ} \mathrm{C}$ and a humidity of $50-55 \%$. For all tensile tests described below, specimen of $15 \mathrm{~mm}$ by $220 \mathrm{~mm}$ was used. The distance between the clamps of the tensile test machine at the moment of clamping is $180 \mathrm{~mm}$. All clamps are mechanical clamps, and the claws themselves are coated with PU. All other parameters are also chosen in accordance with ISO1924-2:2008. All test specimens are taken in the length direction of the paper (machine direction), i.e., the distance of $220 \mathrm{~mm}$ is parallel to the direction of production of the paper. The grammages mentioned below are the averages of the measured values of the test specimen.

\subsection{Short description of the paper types}

10 paper types have been provided by suppliers worldwide. Two paper types ( $C$ and $D$ ) have been supplied with 5 types of organic coating to increases damp resistance of the paper. The coatings are almost invisible and do not influence the recyclability of the paper. The suppliers did not want to share details on these coatings. An overview of the paper types and the data provided by the suppliers can be found in Table 1. A picture of the texture of each paper type can be found in appendix 1, Figs. 14,15,16,17, $18,19,20,21,22,23$.

\subsection{Short description of tests performed}

Tensile tests: conventional tensile test according to ISO 1924-2:2008 [48], 10 identical test specimens per paper type. The force-elongation curves are measured up to breakage of the test specimen.

Elastic contraction test after loading to $30 \mathrm{~N}$ : the conventional tensile test is stopped at a force of $30 \mathrm{~N}$, after which the reverse movement is started while measuring the force as a function of the elongation of the test specimen. 
Table 1 Overview of paper types

\begin{tabular}{llllll}
\hline Paper code & Area density & Origin & Fiber type & Treatment & Intended use \\
\hline & $\mathrm{g} / \mathrm{m}^{2}$ & & & & \\
A & 100 & Europe & Kraft & Bleached + organic coating & Bags \\
B & 99 & Europe & Kraft & Organic coating & Trays \\
C1 & 117 & Europe & Recycled & Organic coating & Bags \\
C2 & 107 & Europe & Recycled & Organic coating & Bags \\
C3 & 116 & Europe & Recycled & Organic coating & Bags \\
C4 & 114 & Europe & Recycled & Organic coating & Bags \\
C5 & 99 & Europe & Recycled & Organic coating & Bags \\
D1 & 202 & Europe & Recycled & Organic coating & Trays \\
D2 & 218 & Europe & Recycled & Organic coating & Trays \\
D3 & 195 & Europe & Recycled & Organic coating & Trays \\
D4 & 221 & Europe & Recycled & Organic coating & Trays \\
D5 & 201 & Europe & Recycled & Organic coating & Trays \\
E & 35 & Canada & Recycled & None & Towels \\
F & 94 & Europe & Recycled & Crepe & Decoration \\
G & 79 & USA & Recycled & None & Packaging \\
H & 90 & USA & Recycled & Plastic coating & Packaging \\
I & 58 & Europe & Kraft & None & Packaging \\
P & 52 & 2,63 & Kraft & Bleached & Printing \\
\hline
\end{tabular}
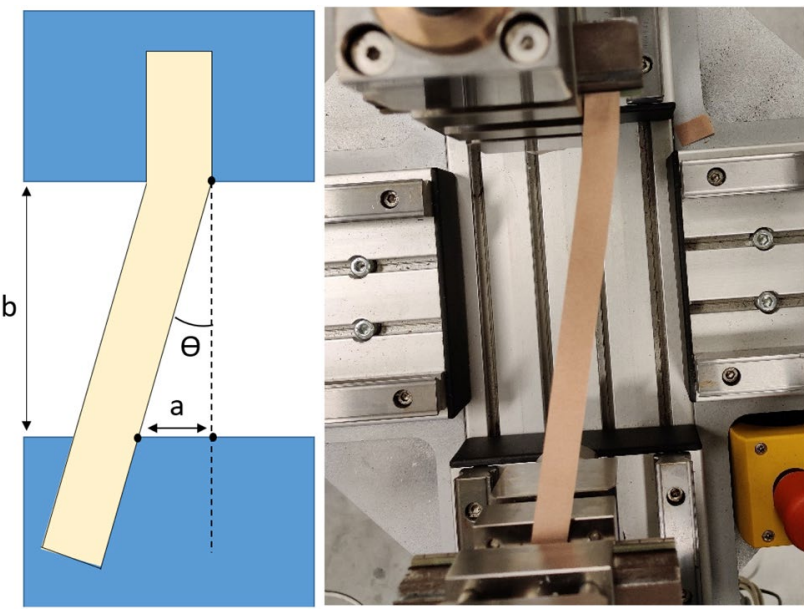

Fig. 5 Top view of test specimen clamped under angle $\Theta$

Elastic contraction test after loading up to $50 \%$ of the average tensile strength.

Tear tests: As far as is known, there are no standardized tests available to check to what extent the screw angle can be changed during winding. Therefore, a variant of the conventional tensile test is used: the distance between the clamps is set at $180 \mathrm{~mm}$. The test specimen is clamped in one clamp parallel to the pulling direction and in the other clamp at an angle $\Theta$, where $\tan \theta=a b$ (Fig. 5). The test specimen is pre-stressed with negligible preload during clamping.

\subsection{Results of the material tests}

The measured force-elongation curves for all test specimen are added in appendix 2, Figs. 24, 25, 26, 27, 28, 29, $30,31,32,33,34,35,36,37,38,39,40,41$. In Fig. 6, the values of the force at given elongation are averaged out for the 10 test specimen per paper type. This shows a very clear effect of the post-treatment and coating of paper types $C$ and $D$, which also means, among other things, that the forces are not proportional to the grammages per $\mathrm{m}^{2}$. Figure 7, therefore, shows standardized curves (force per grammage and per width as a function of elongation). For information purposes, Figs. 6 and 7 also include a curve for a typical plastic stretch film (SF) with a grammage of $100 \mathrm{~g} /$ $\mathrm{m}^{2}$. A summary of the most important values with associated standard deviation can be found in Table 2 .

In the context of the desired properties for paper winding, it was decided after these tensile tests to focus on paper types $A, B, C$ and $D$ for the elastic contraction tests and the tear tests. Paper I is not retained, although it is about as strong as paper $A$ and $B$, but the elongation at break is much lower. Paper $F$ is also not retained after comparison with papers $C$ and $D$ because $F$ consists of new fibers, and the strength at lower values of elongation is much lower than for paper $D$ and even paper $C$.

Table 3 summarizes the averaged results of the tests on the elastic contraction after a force of $30 \mathrm{~N}$. The total elongation at $30 \mathrm{~N}$ is shown in column "total elongation", and the remaining elongation after returning to a force of $0 \mathrm{~N}$ is shown in column "permanent elongation". The other 
Fig. 6 Averaged results of tensile tests

Fig. 7 Normalized averaged results of tensile tests
Tensile test paper

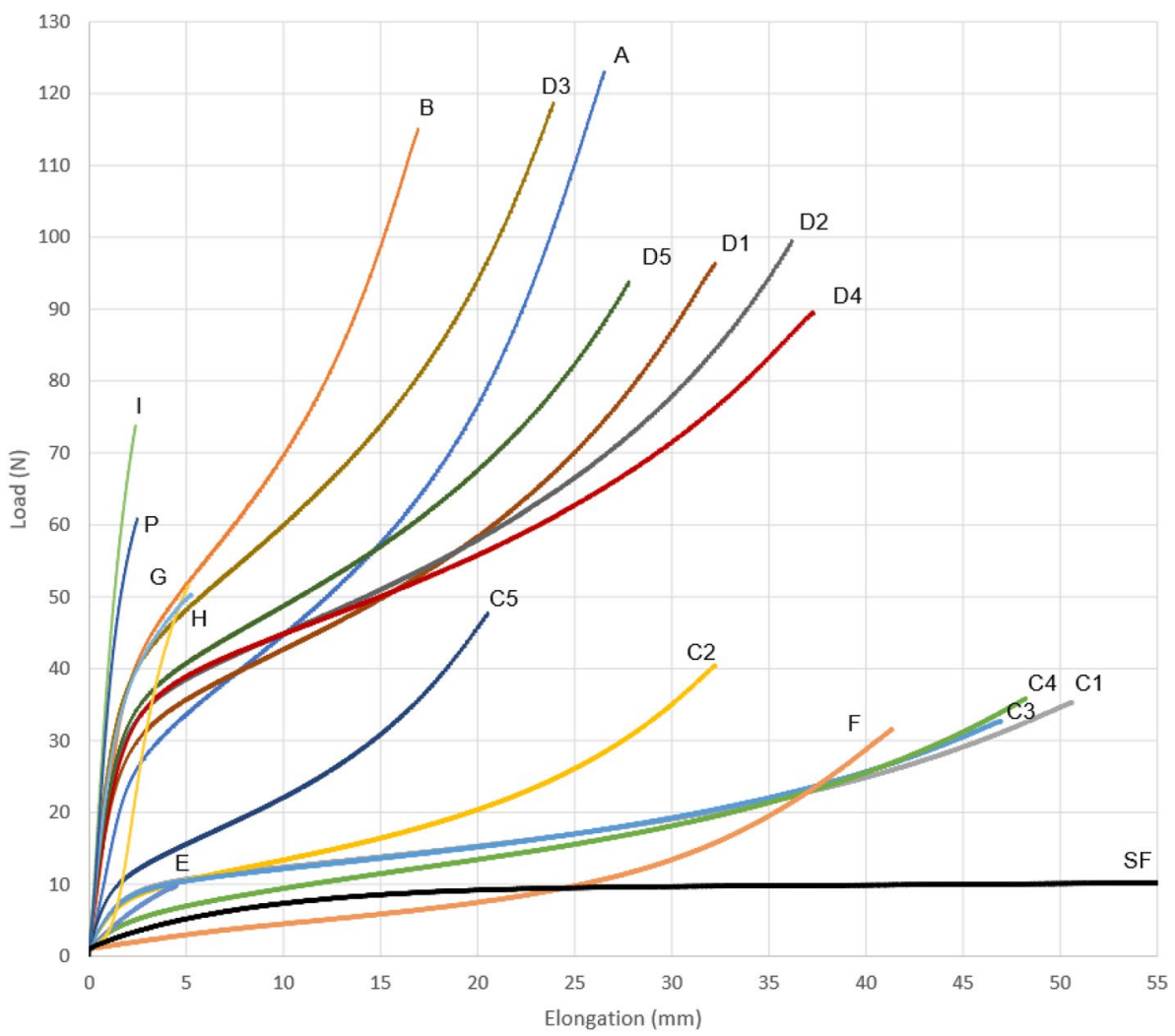

Specific tensile test paper

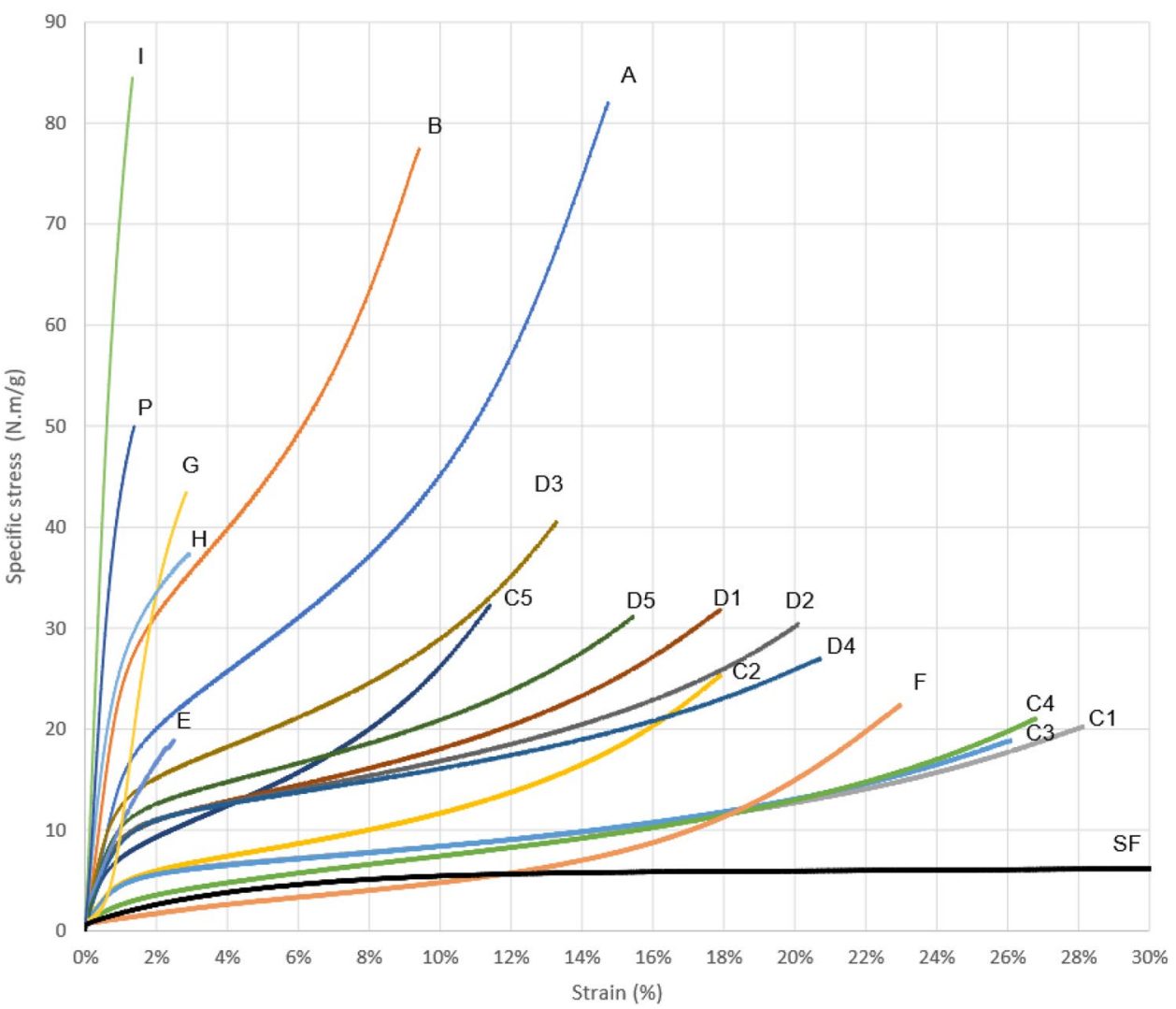


Table 2 Summary of results of tensile tests

\begin{tabular}{|c|c|c|c|c|c|c|c|c|}
\hline \multirow[t]{2}{*}{ Paper type } & \multirow[t]{2}{*}{ Area density } & \multicolumn{2}{|c|}{ Elongation } & \multicolumn{2}{|c|}{ Breaking load } & \multicolumn{2}{|c|}{ Specific breaking stress } & \multirow{2}{*}{$\begin{array}{l}\text { Breaking strain } \\
\text { Average }\end{array}$} \\
\hline & & Average & Std. deviation & Average & Std. deviation & Average & Std. deviation & \\
\hline & $\mathrm{g} / \mathrm{m}^{2}$ & $\mathrm{Mm}$ & $\mathrm{Mm}$ & $\mathrm{N}$ & $\mathrm{N}$ & $\mathrm{Nm} / \mathrm{g}$ & $\mathrm{Nm} / \mathrm{g}$ & $\%$ \\
\hline A & 100 & 26,32 & 0,57 & 122,66 & 4,89 & 81,77 & 3,26 & 14,6 \\
\hline B & 99 & 16,71 & 0,82 & 113,07 & 7,97 & 76,14 & 5,37 & 9,3 \\
\hline $\mathrm{C} 1$ & 117 & 50,32 & 1,43 & 35,44 & 2,05 & 20,27 & 1,17 & 28,0 \\
\hline $\mathrm{C} 2$ & 107 & 32,77 & 0,91 & 39,62 & 2,76 & 24,78 & 1,73 & 18,2 \\
\hline $\mathrm{C} 3$ & 116 & 47,29 & 1,84 & 32,01 & 1,84 & 18,44 & 1,06 & 26,3 \\
\hline $\mathrm{C} 4$ & 114 & 48,80 & 2,39 & 35,51 & 3,04 & 20,83 & 1,78 & 27,1 \\
\hline $\mathrm{C} 5$ & 99 & 20,35 & 0,87 & 47,72 & 3,90 & 32,27 & 2,64 & 11,3 \\
\hline D1 & 202 & 31,83 & 2,28 & 95,51 & 10,15 & 31,53 & 3,35 & 17,7 \\
\hline D2 & 218 & 36,28 & 1,22 & 100,16 & 6,46 & 30,64 & 1,98 & 20,2 \\
\hline D3 & 195 & 23,88 & 0,77 & 117,58 & 6,46 & 40,13 & 2,21 & 13,3 \\
\hline D4 & 221 & 37,31 & 1,40 & 90,99 & 4,29 & 27,39 & 1,29 & 20,7 \\
\hline D5 & 201 & 27,87 & 1,25 & 95,69 & 6,64 & 31,78 & 2,20 & 15,5 \\
\hline$E$ & 35 & 4,64 & 0,26 & 9,86 & 0,62 & 19,05 & 1,20 & 2,6 \\
\hline $\mathrm{F}$ & 94 & 41,32 & 2,93 & 31,97 & 3,85 & 22,63 & 2,73 & 23,0 \\
\hline $\mathrm{G}$ & 79 & 5,15 & 0,64 & 50,25 & 4,91 & 42,24 & 4,13 & 2,9 \\
\hline $\mathrm{H}$ & 90 & 5,42 & 1,13 & 50,96 & 3,85 & 37,82 & 2,86 & 3,0 \\
\hline I & 58 & 2,34 & 0,17 & 72,62 & 5,07 & 83,16 & 5,81 & 1,3 \\
\hline$P$ & 52 & 2,63 & 0,17 & 61,65 & 3,30 & 50,63 & 2,71 & 1,5 \\
\hline
\end{tabular}

Table 3 Averaged results of elastic contraction tests following a force of $30 \mathrm{~N}$

\begin{tabular}{|c|c|c|c|c|c|c|c|c|}
\hline \multirow[b]{2}{*}{ Paper type } & \multicolumn{3}{|l|}{ Elongation } & \multicolumn{3}{|c|}{ Strain = elongation/sample length } & \multicolumn{2}{|c|}{ Type of strain distribution } \\
\hline & $\begin{array}{l}\text { Total elon- } \\
\text { gation }(\mathrm{mm})\end{array}$ & $\begin{array}{l}\text { Permanent } \\
\text { elongation } \\
(\mathrm{mm})\end{array}$ & $\begin{array}{l}\text { Elastic elon- } \\
\text { gation }(\mathrm{mm})\end{array}$ & $\begin{array}{l}\text { Total strain } \\
(\%)\end{array}$ & $\begin{array}{l}\text { Perma- } \\
\text { nent } \\
\text { strain } \\
(\%)\end{array}$ & $\begin{array}{l}\text { Elastic } \\
\text { strain (\%) }\end{array}$ & $\begin{array}{l}\text { Perman } \\
\text { (\% of total strain) }\end{array}$ & $\begin{array}{l}\text { Elastic } \\
\text { (\% of total strain) }\end{array}$ \\
\hline A & 3,60 & 2,18 & 1,43 & 2,00 & 1,21 & 0,79 & 60,42 & 39,58 \\
\hline $\mathrm{B}$ & 1,68 & 0,69 & 0,99 & 0,93 & 0,38 & 0,55 & 40,90 & 59,10 \\
\hline $\mathrm{C} 1$ & 46,16 & 42,63 & 3,53 & 25,64 & 23,68 & 1,96 & 92,35 & 7,65 \\
\hline $\mathrm{C} 2$ & 28,48 & 25,57 & 2,91 & 15,82 & 14,21 & 1,62 & 89,78 & 10,22 \\
\hline $\mathrm{C} 3$ & 45,89 & 42,23 & 3,66 & 25,49 & 23,46 & 2,03 & 92,02 & 7,98 \\
\hline $\mathrm{C} 4$ & 43,99 & 40,53 & 3,46 & 24,44 & 22,52 & 1,92 & 92,13 & 7,87 \\
\hline $\mathrm{C} 5$ & 15,08 & 12,70 & 2,38 & 8,38 & 7,06 & 1,32 & 84,22 & 15,78 \\
\hline D1 & 5,66 & 4,27 & 1,39 & 3,15 & 2,37 & 0,77 & 75,40 & 24,60 \\
\hline D2 & 5,47 & 3,99 & 1,48 & 3,04 & 2,22 & 0,82 & 72,94 & 27,06 \\
\hline D3 & 2,42 & 1,37 & 1,05 & 1,34 & 0,76 & 0,58 & 56,69 & 43,31 \\
\hline D4 & 5,65 & 4,03 & 1,62 & 3,14 & 2,24 & 0,90 & 71,34 & 28,66 \\
\hline D5 & 3,72 & 2,45 & 1,27 & 2,07 & 1,36 & 0,71 & 65,86 & 34,14 \\
\hline
\end{tabular}

columns are calculated values. Figure 8 illustrates the split into permanent and elastic elongation.

Based on these results, the preferred paper grade could be $C$ which shows the highest elastic elongation. Figure 7 , however, shows that a tension force of $30 \mathrm{~N}$ comes close to the tensile strength of paper $C$ with the risk of the paper tearing at the time of impact loading or even during winding. Therefore, an alternative split between permanent and elastic elongation at a tension force of $50 \%$ of the tensile strength has been made, as shown in Table 4 .

A graphical representation of these data can be found in Fig. 9.

The elastic elongation available to absorb vibrations and impact forces is now comparable for paper grades $C$ 
Fig. 8 Permanent and elastic elongation
Elastic contraction test

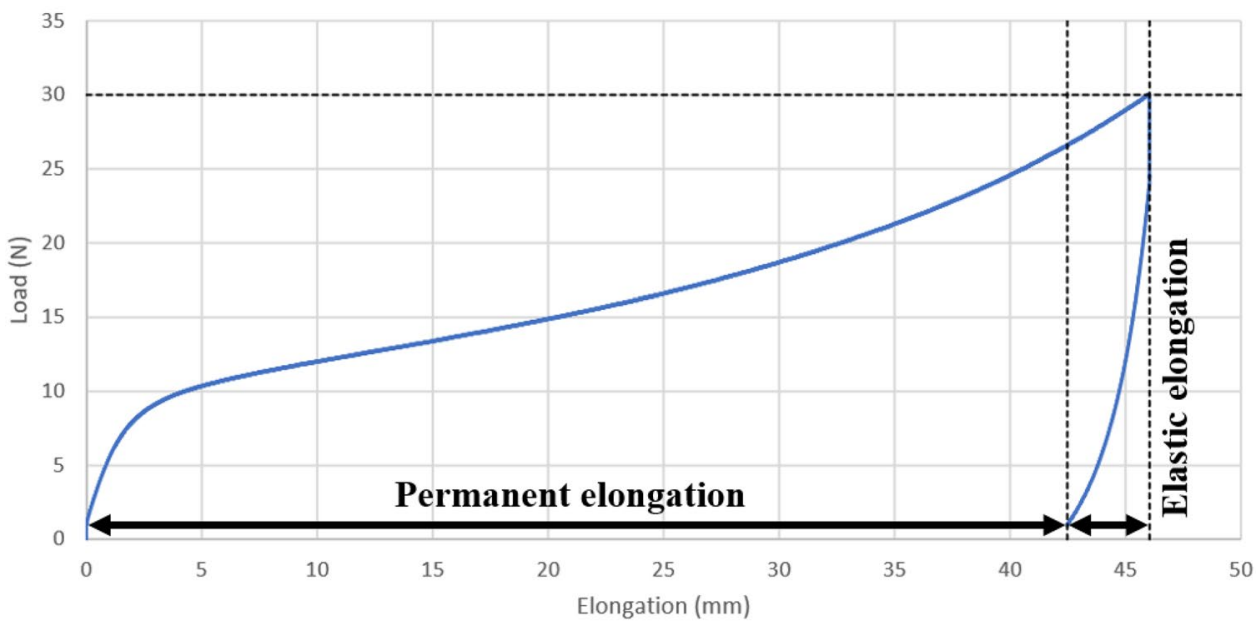

Table 4 Averaged results of elastic contraction tests following a force of $50 \%$ of ultimate force

\begin{tabular}{|c|c|c|c|c|c|c|c|c|}
\hline \multirow[b]{2}{*}{ Paper type } & \multicolumn{3}{|l|}{ Elongation } & \multicolumn{3}{|c|}{ Strain = elongation/sample length } & \multicolumn{2}{|c|}{ Type of strain distribution } \\
\hline & $\begin{array}{l}\text { Total elon- } \\
\text { gation }(\mathrm{mm})\end{array}$ & $\begin{array}{l}\text { Permanent } \\
\text { elongation } \\
(\mathrm{mm})\end{array}$ & $\begin{array}{l}\text { Elastic elon- } \\
\text { gation }(\mathrm{mm})\end{array}$ & $\begin{array}{l}\text { Total strain } \\
(\%)\end{array}$ & $\begin{array}{l}\text { Perma- } \\
\text { nent } \\
\text { strain } \\
(\%)\end{array}$ & $\begin{array}{l}\text { Elastic } \\
\text { strain (\%) }\end{array}$ & $\begin{array}{l}\text { Perman } \\
\text { (\% of total strain) }\end{array}$ & $\begin{array}{l}\text { Elastic } \\
\text { (\% of total strain) }\end{array}$ \\
\hline$A$ & 14,14 & 11,88 & 2,25 & 7,85 & 6,60 & 1,25 & 84,07 & 15,93 \\
\hline B & 6,91 & 4,99 & 1,92 & 3,84 & 2,77 & 1,07 & 72,19 & 27,81 \\
\hline C1 & 26,05 & 22,39 & 3,66 & 14,47 & 12,44 & 2,03 & 85,96 & 14,04 \\
\hline $\mathrm{C} 2$ & 20,48 & 17,29 & 3,19 & 11,38 & 9,61 & 1,77 & 84,42 & 15,58 \\
\hline $\mathrm{C} 3$ & 22,99 & 19,44 & 3,55 & 12,77 & 10,80 & 1,97 & 84,56 & 15,44 \\
\hline $\mathrm{C} 4$ & 27,79 & 23,91 & 3,88 & 15,44 & 13,28 & 2,15 & 86,05 & 13,95 \\
\hline C5 & 7,09 & 4,74 & 2,35 & 3,94 & 2,63 & 1,31 & 66,84 & 33,16 \\
\hline D1 & 8,91 & 5,79 & 3,12 & 4,95 & 3,22 & 1,73 & 65,00 & 35,00 \\
\hline D2 & 15,46 & 11,88 & 3,58 & 8,59 & 6,60 & 1,99 & 76,85 & 23,15 \\
\hline D3 & 9,67 & 7,03 & 2,64 & 5,37 & 3,91 & 1,47 & 72,72 & 27,28 \\
\hline D4 & 13,69 & 10,19 & 3,49 & 7,60 & 5,66 & 1,94 & 74,47 & 25,53 \\
\hline D5 & 9,57 & 6,71 & 2,86 & 5,32 & 3,73 & 1,59 & 70,12 & 29,88 \\
\hline
\end{tabular}

and $D$ and slightly greater than for paper grades $A$ and $B$. The additional permanent elongation is greater for paper grades $C$. The post-treatments and coatings have a clear added value, as can be seen from the comparison between C1-C4 on the one hand and C5 on the other.

The results of the tear tests are summarized in Table 5. At this stage of the investigation, the tear tests are limited to paper grades $A, B$ and $C 1$. Grades $A$ and $B$ are selected because of their high tensile strength, $C 1$ is the paper type with the highest elastic stretchability.

The tear test curves averaged over the 10 test specimen can found in Figs. 10, 11, 12.

The decrease in strength as a function of the misalignment angle $\theta$ is graphically represented in Fig. 13.
Figure 13 shows that the strength of papers $A$ and $B$ is more subject to "misalignment" than the strength of paper C1, which could perhaps be expected based on the greater stretchability of paper $C$.

\section{5. Observations, conclusions, further research}

\subsection{Observations}

The 5 requirements set at the start of the investigation for paper to qualify as a wrapping material for suspension packaging are evaluated: 
Fig. 9 Elongation for each paper at $50 \%$ of their breaking load
Elongation at $50 \%$ of breaking load

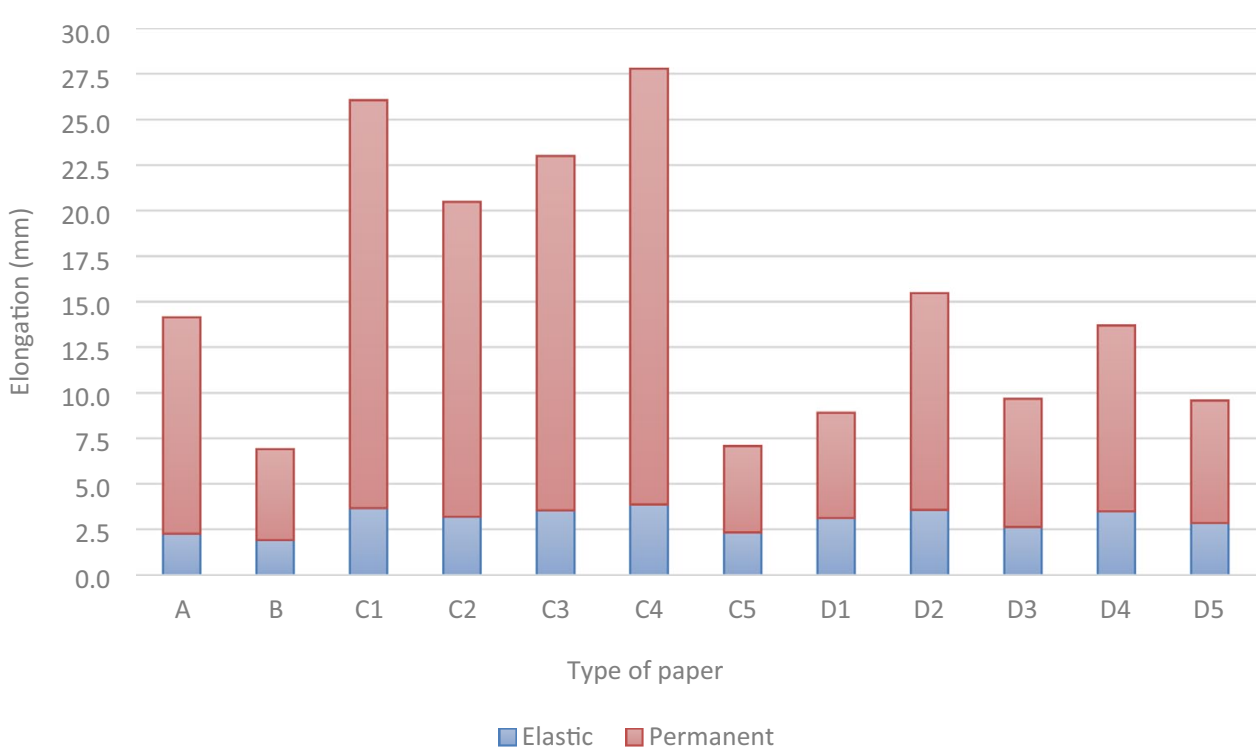

Table 5 Averaged results of tear tests

\begin{tabular}{|c|c|c|c|c|c|c|c|c|}
\hline \multirow[t]{2}{*}{ Paper } & \multirow{2}{*}{$\begin{array}{l}\text { Misalignment } \\
\text { distance a } \\
\text { Mm }\end{array}$} & \multirow{2}{*}{$\begin{array}{l}\text { Misalignment } \\
\text { angle } \theta \\
\text { degrees }\end{array}$} & \multicolumn{2}{|c|}{$\begin{array}{l}\text { Max force } \\
\text { (N) }\end{array}$} & \multicolumn{2}{|c|}{$\begin{array}{l}\text { Difference with } \\
\text { zero misalignment }\end{array}$} & \multicolumn{2}{|c|}{$\begin{array}{l}\text { Max elongation } \\
(\mathrm{mm})\end{array}$} \\
\hline & & & Avg & St.dev & \pm & $\%$ & $\mathrm{~mm}$ & St.dev. \\
\hline \multirow[t]{6}{*}{ A } & 0 & 0,00 & 122,68 & 4,89 & -0 & $-0 \%$ & 26,34 & 0,57 \\
\hline & 15 & 4,76 & 123,85 & 7,94 & $+1,2$ & $+1 \%$ & 24,51 & 0,83 \\
\hline & 25 & 7,91 & 111,86 & 6,66 & $-10,8$ & $-9 \%$ & 23,88 & 1,02 \\
\hline & 35 & 11,00 & 87,29 & 6,81 & $-35,4$ & $-29 \%$ & 20,78 & 1,49 \\
\hline & 45 & 14,04 & 78,95 & 7,42 & $-43,7$ & $-36 \%$ & 19,76 & 1,97 \\
\hline & 55 & 16,99 & 65,04 & 4,30 & $-57,6$ & $-47 \%$ & 17,28 & 1,45 \\
\hline \multirow[t]{6}{*}{ B } & 0 & 0,00 & 113,07 & 7,97 & -0 & $-0 \%$ & 16,71 & 0,82 \\
\hline & 15 & 4,76 & 108,50 & 8,02 & $-4,6$ & $-4 \%$ & 15,70 & 1,12 \\
\hline & 25 & 7,91 & 94,98 & 3,87 & $-18,1$ & $-16 \%$ & 14,91 & 0,68 \\
\hline & 35 & 11,00 & 76,64 & 4,12 & $-36,4$ & $-32 \%$ & 11,98 & 0,76 \\
\hline & 45 & 14,04 & 65,41 & 4,65 & $-47,7$ & $-42 \%$ & 9,70 & 1,10 \\
\hline & 55 & 16,99 & 44,44 & 13,74 & $-68,6$ & $-61 \%$ & 6,91 & 2,03 \\
\hline \multirow[t]{6}{*}{ C1 } & 0 & 0,00 & 35,44 & 2,05 & -0 & $-0 \%$ & 50,32 & 1,43 \\
\hline & 15 & 4,76 & 30,53 & 2,49 & $-4,9$ & $-13 \%$ & 47,53 & 1,78 \\
\hline & 25 & 7,91 & 31,01 & 3,33 & $-4,4$ & $-12 \%$ & 49,08 & 3,13 \\
\hline & 35 & 11,00 & 28,62 & 1,82 & $-6,8$ & $-18 \%$ & 47,90 & 1,89 \\
\hline & 45 & 14,04 & 24,99 & 1,70 & $-10,4$ & $-27 \%$ & 44,57 & 2,21 \\
\hline & 55 & 16,99 & 22,60 & 2,65 & $-12,8$ & $-33 \%$ & 44,61 & 2,65 \\
\hline
\end{tabular}

1. Ssignificant elongation in the longitudinal direction (machine direction): the elongation at break is $9 \%$ or more for paper types A, B, C and D.

2. Part of the elongation is elastic: the elastic elongation after loading up to $50 \%$ of the tensile strength is 1 to $2 \%$ for paper types $A, B, C$ and $D$.

3. A higher breaking strain may be advantageous: grades $A, B$ and I score best on this criterion
4. Resists tensile forces in combination with smaller transverse forces: in absolute values A and B score best, but $\mathrm{C} 1$ scores best in proportion to its tensile strength

5. Is coated or can be coated so that its mechanical properties are preserved during transport in damp conditions: according to the suppliers, $A, B$ and $C 1$ meet this criterion. 
Fig. 10 Tear test curves of paper A per misalignment
Tear test - paper $\mathrm{A}$

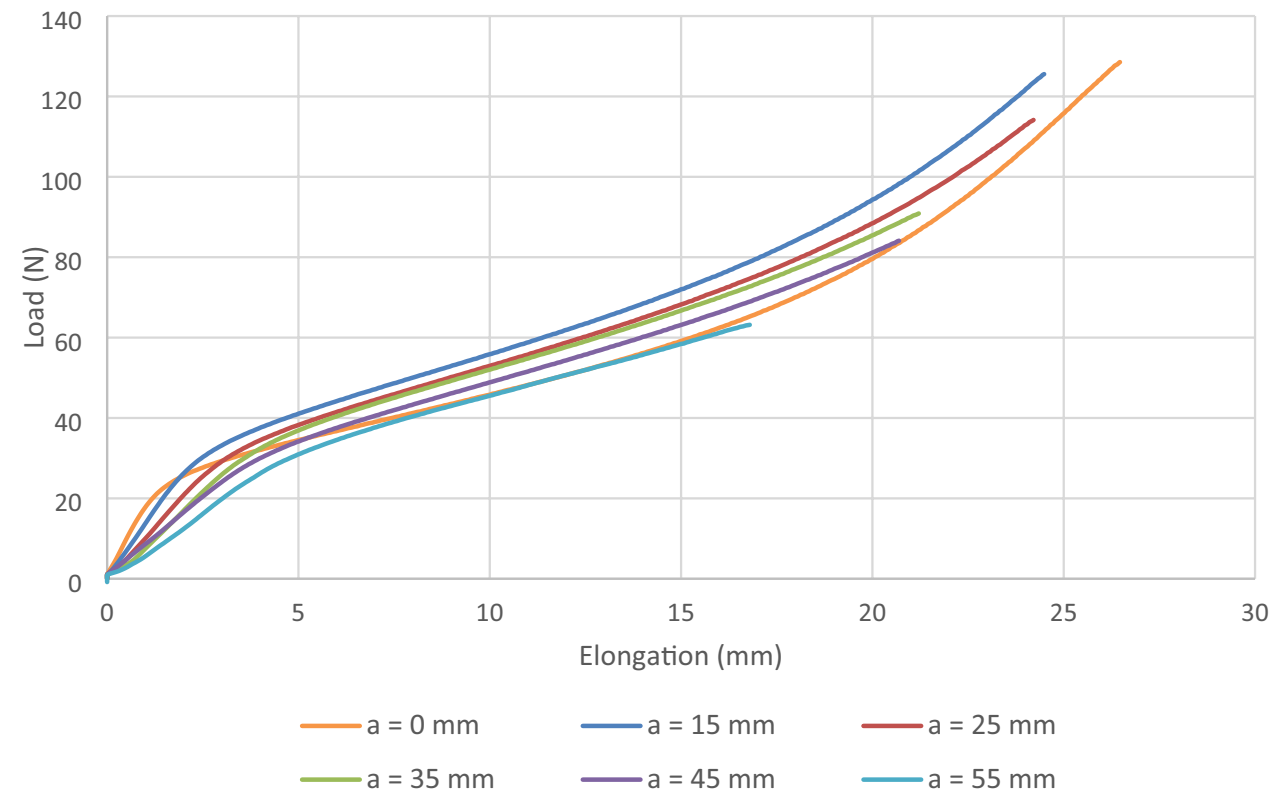

Fig. 11 Tear test curves of paper B per misalignment

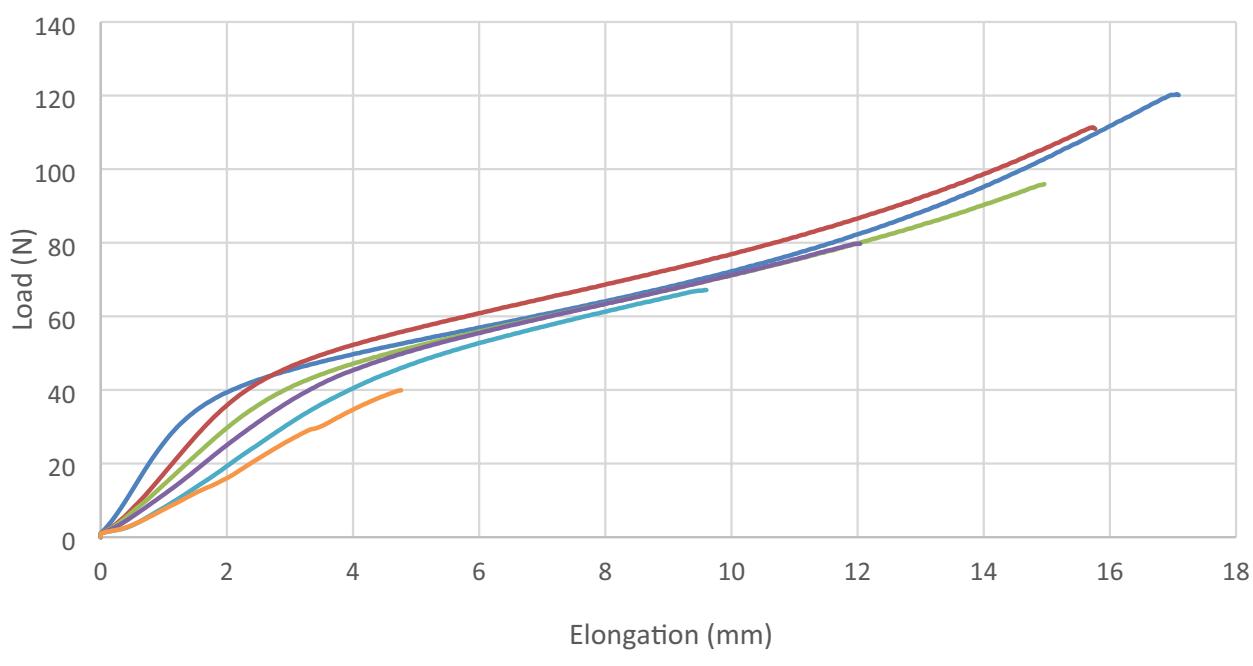

\subsection{Conclusion}

Based on the material tests carried out, it is not possible to conclude with certainty that plastic stretch film can be replaced by commercial paper as winding material for suspension packaging. The tensile curves of plastic stretch film types and so-called stretchable paper types can hardly be compared:

\section{SN Applied Sciences}

- The total stretch ability of paper is far below the stretch ability of plastic stretch film

- The paper tensile curves do not show a flat zone that would allow easy wrapping

- The elastic part of the elongation of paper is very low and may be critical

Since this elastic elongation at $50 \%$ of the tensile strength is the highest for paper type $C$ (with small differences between 
Fig. 12 Tear test curves of paper $\mathrm{C} 1$ per misalignment
Fig. 13 Breaking load as a function of tearing angle $\theta$

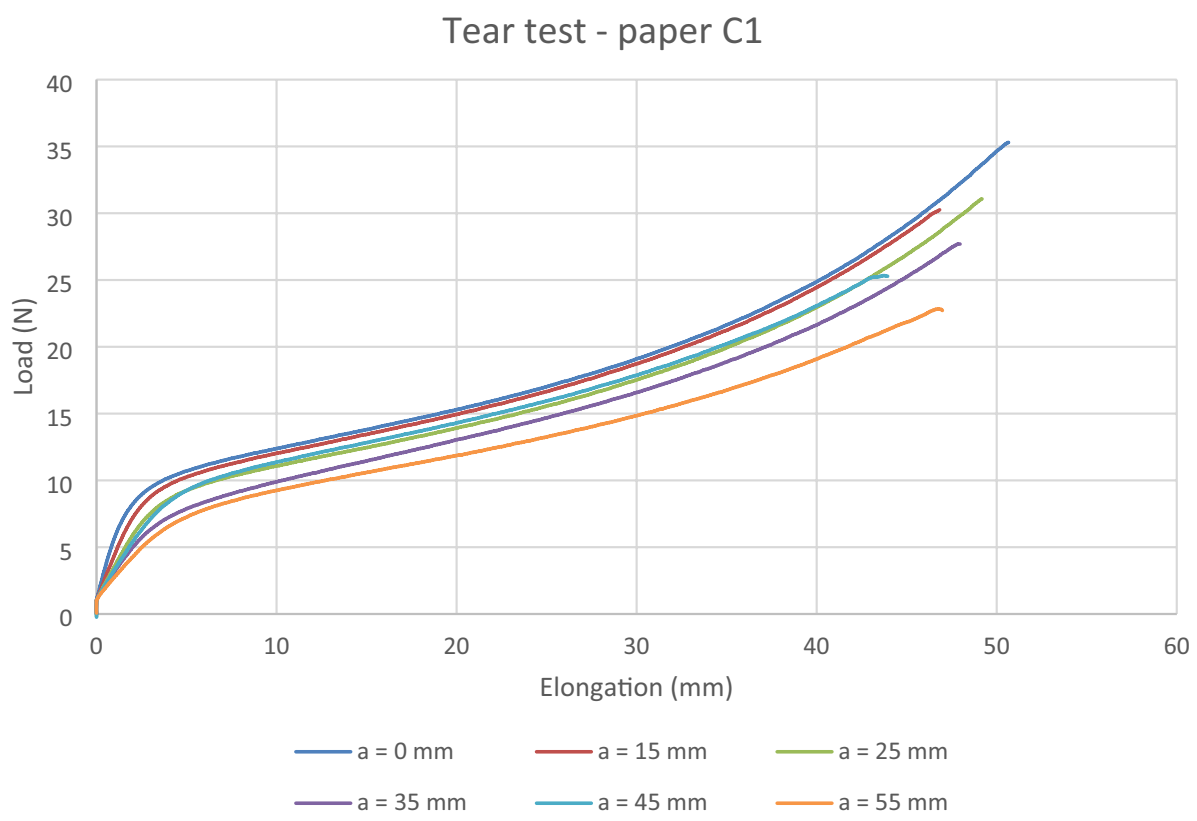

Tearing strength

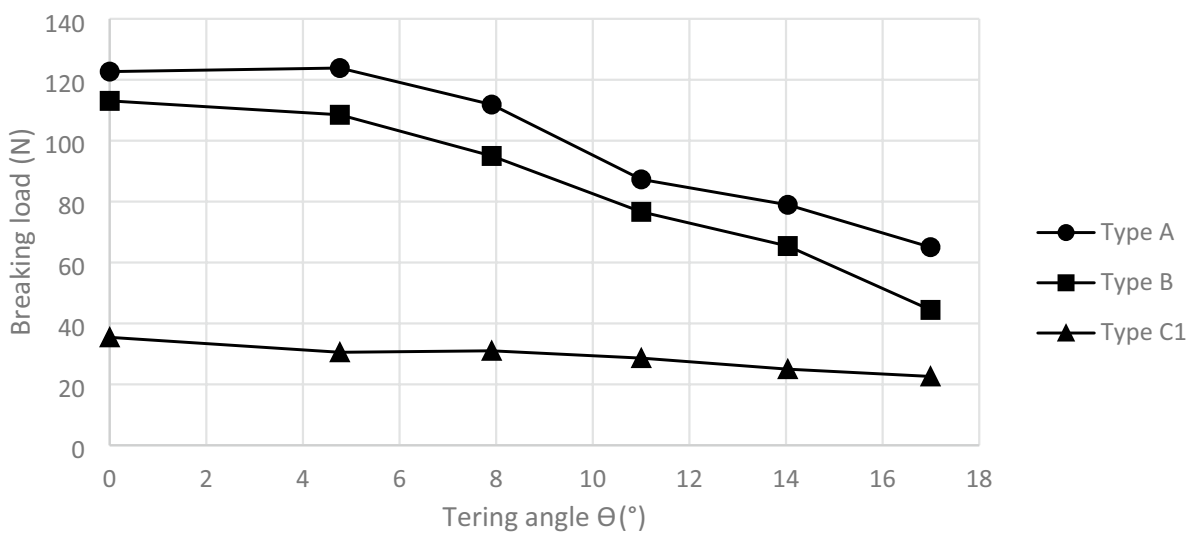

$\mathrm{C} 1, \mathrm{C} 3$ and $(4)$, the conclusion of this research is that paper $\mathrm{C}$ may be indicated as a test material in further research.

\subsection{Further research}

The final conclusion regarding the use of paper as a wrapping material in suspension packaging will have to be based on drop tests of parcels with suspension packaging. In order to be able to perform relevant drop tests, a wrapping machine that is able to control the tension in the strip of paper being wrapped must be developed. The tensile curves and the tear test curves described above can serve as a starting point to choose the setpoints for the tension in the wrapping paper. Further research is needed as well to find an appropriate connection method for both ends of the paper strips on the base plate and to choose an appropriate coating for the wrapping paper.
Funding This study was funded by KU Leuven.

\section{Declarations}

Conflict of interest The authors declare that they have no conflict of interest.

Human or animal rights This research does not contain any studies with human participants or animals performed by any of the authors.

Informed concent Informed consent was obtained from all individual participants included in the study.

Open Access This article is licensed under a Creative Commons Attribution 4.0 International License, which permits use, sharing, adaptation, distribution and reproduction in any medium or format, as long as you give appropriate credit to the original author(s) and the source, provide a link to the Creative Commons licence, and indicate if changes were made. The images or other third party material in this 
article are included in the article's Creative Commons licence, unless indicated otherwise in a credit line to the material. If material is not included in the article's Creative Commons licence and your intended use is not permitted by statutory regulation or exceeds the permitted use, you will need to obtain permission directly from the copyright holder. To view a copy of this licence, visit http://creativecommons. org/licenses/by/4.0/.

Fig. $1415 \mathrm{~mm}$ wide sample of paper A

Fig. $1515 \mathrm{~mm}$ wide sample of paper B

Fig. $1615 \mathrm{~mm}$ wide sample of paper $\mathrm{C}$

Fig. $1715 \mathrm{~mm}$ wide sample of paper D

Fig. $1815 \mathrm{~mm}$ wide sample of paper E

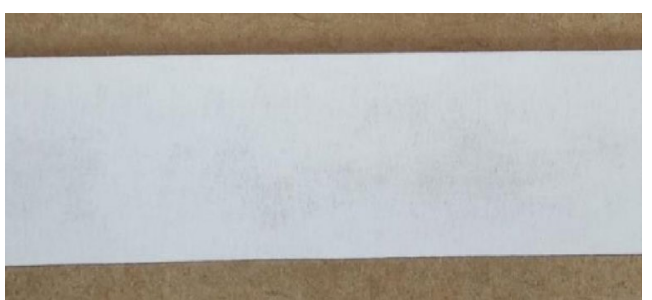

Paper A: bleached kraft paper with a coating of organic material intended for carrier bags, European origin, $100 \mathrm{~g} / \mathrm{m}^{2}$

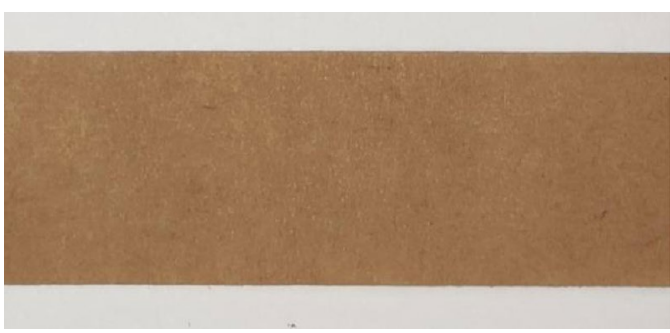

Paper B: unbleached kraft paper with a coating of organic material, European origin, $99 \mathrm{~g} / \mathrm{m}^{2}$

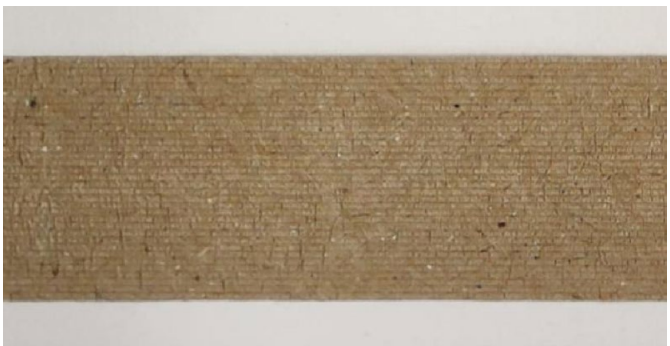

Paper C: paper from recycled fibers, $\mathrm{C} 1$ through $\mathrm{C} 4$ are post-treated in several ways and coated with an organic material, produced (prior to coating) as $100 \mathrm{~g} / \mathrm{m}^{2}$ but measured grammage of the test specimen $\mathrm{C} 1: 117 \mathrm{~g} / \mathrm{m}^{2} ; \mathrm{C} 2: 107 \mathrm{~g} / \mathrm{m}^{2} ; \mathrm{C} 3: 116 \mathrm{~g} / \mathrm{m}^{2}$; $\left.\mathrm{C} 4: 114 \mathrm{~g} / \mathrm{m}^{2} ; \mathrm{C} 5: 99 \mathrm{~g} / \mathrm{m}^{2}\right)$.

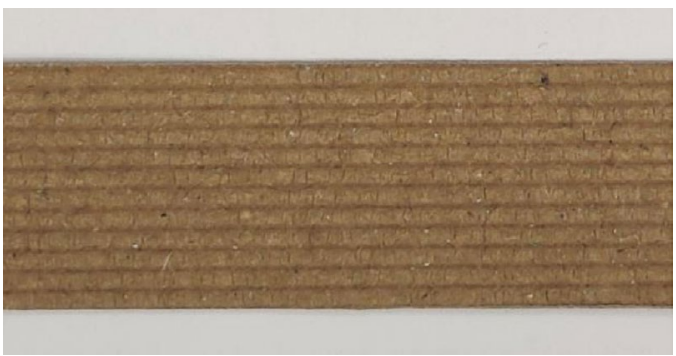

Paper D: paper from recycled fibers, post-treated in various ways and coated with an organic material, codes D1-D5, origin Europe, produced uncoated as $200 \mathrm{~g} / \mathrm{m}^{2}$ but measured grammage of the test specimen D1:202g/m²; D2:218g/m² D3:195g/m²; D4:221g $/ \mathrm{m}^{2}$; D5:201g/m²)

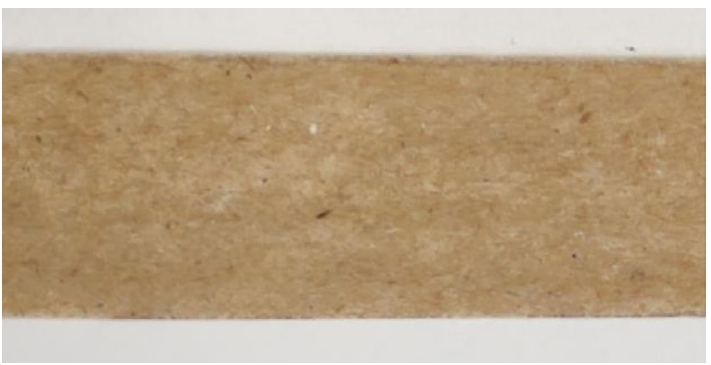

Paper E: unbleached paper from recycled fibers, intended for paper towels, origin Canada, $35 \mathrm{~g} / \mathrm{m}^{2}$ 
Fig. $1915 \mathrm{~mm}$ wide sample of paper $F$

Fig. $2015 \mathrm{~mm}$ wide sample of paper $\mathrm{G}$

Fig. $2115 \mathrm{~mm}$ wide sample of paper $\mathrm{H}$

Fig. $2215 \mathrm{~mm}$ wide sample of paper I

Fig. $2315 \mathrm{~mm}$ wide sample of paper $\mathrm{P}$

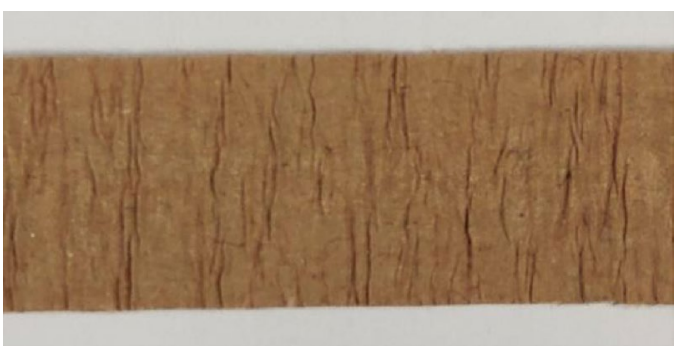

Paper F: unbleached crepe paper, little or no recycled fibers, origin Europe, $94 \mathrm{~g} / \mathrm{m}^{2}$

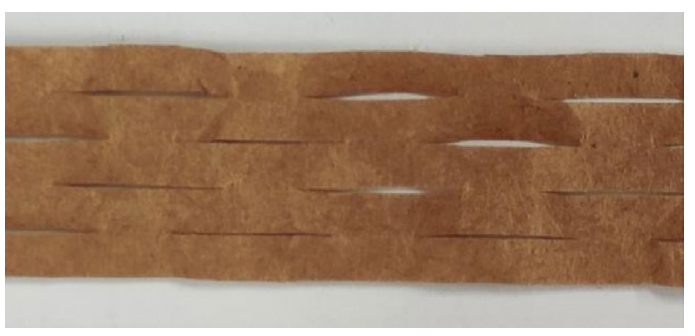

Paper G: unbleached kraft paper with perforations parallel to the machine direction, origin USA, $79 \mathrm{~g} / \mathrm{m}^{2}$

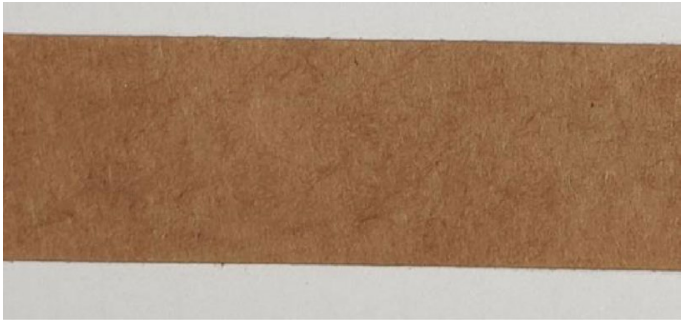

Paper H: unbleached kraft paper with unknown coating, intended for wrapping paper, origin USA, $90 \mathrm{~g} / \mathrm{m}^{2}$

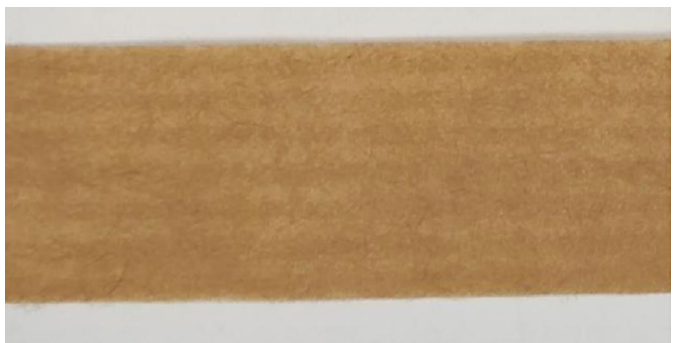

Paper I: unbleached kraft paper without coating, intended for wrapping paper, origin Europe, $58 \mathrm{~g} / \mathrm{m}^{2}$

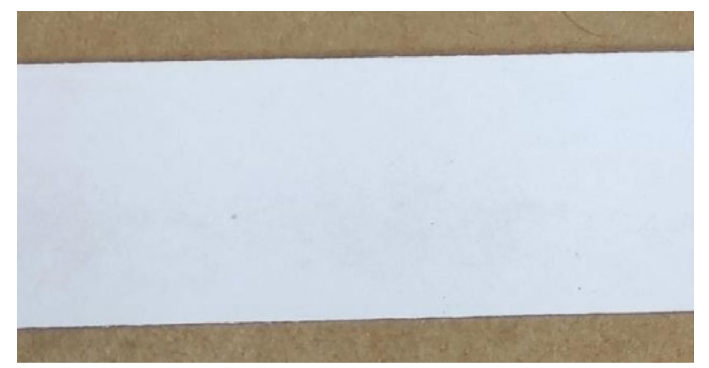

Paper P: randomly selected printing paper, composition not known, origin Europe, $52 \mathrm{~g} / \mathrm{m}^{2}$

\section{Appendix 2}

See Figs. 24, 25, 26, 27, 28, 29, 30, 31, 32, 33, 34, 35, 36, 37, $38,39,40,41$. 
Fig. 24 Force elongation curves of individual specimen of paper $A$

Fig. 25 Force elongation curves of individual specimen of paper B
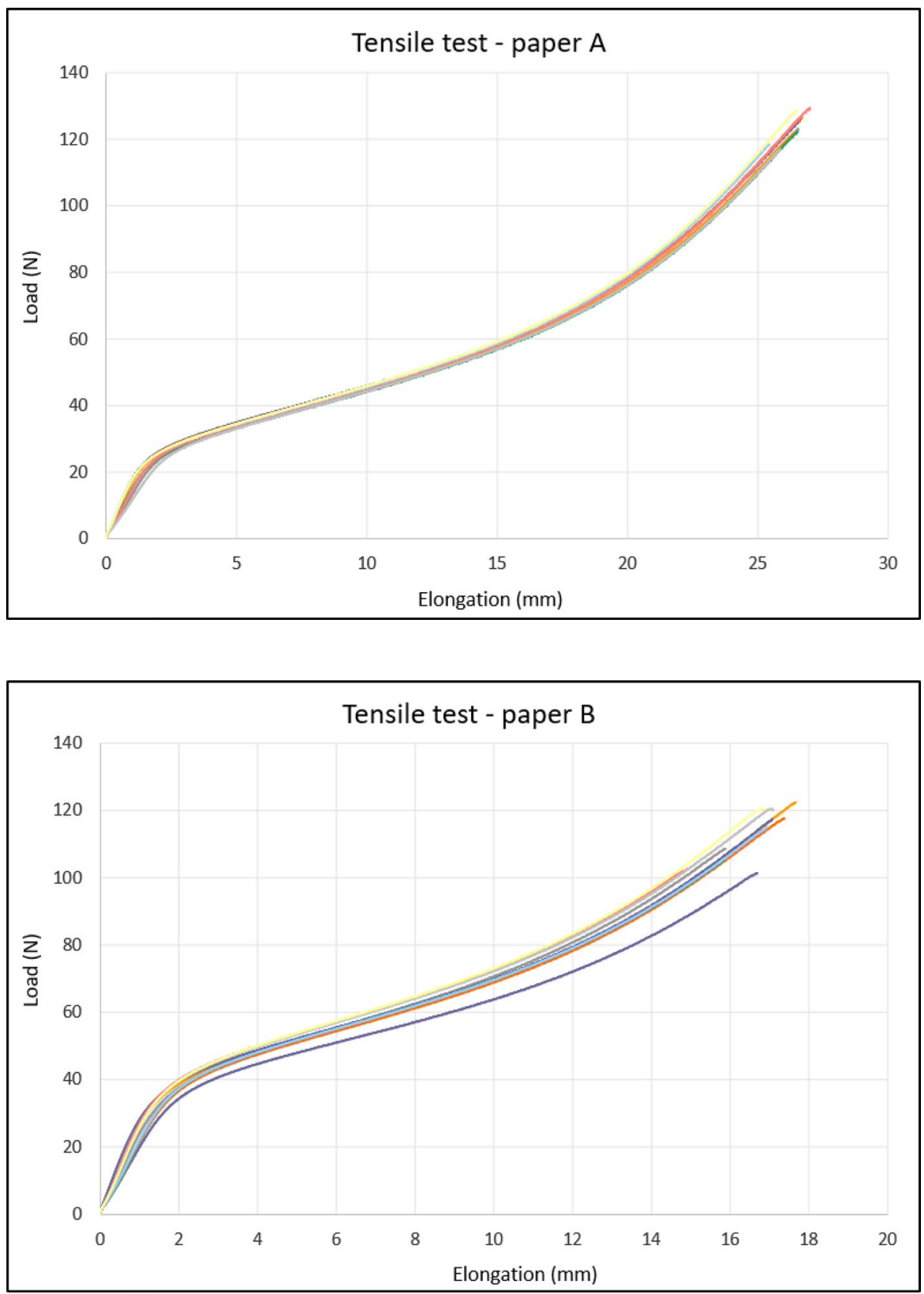
Fig. 26 Force elongation curves of individual specimen of paper $\mathrm{C} 1$
Fig. 27 Force elongation curves of individual specimen of paper $\mathrm{C} 2$
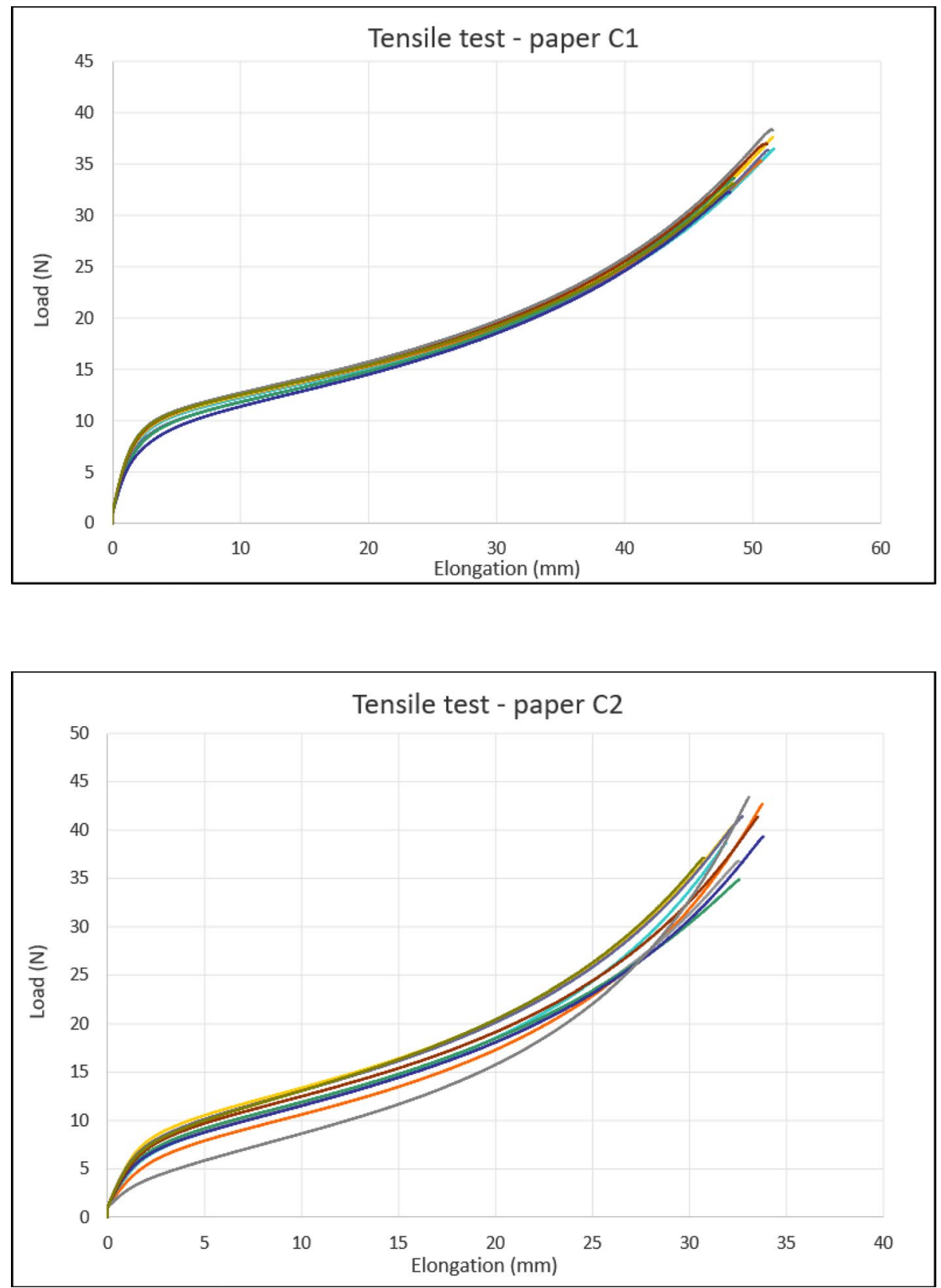
Fig. 28 Force elongation curves of individual specimen of paper $\mathrm{C} 3$
Fig. 29 Force elongation curves of individual specimen of paper C4
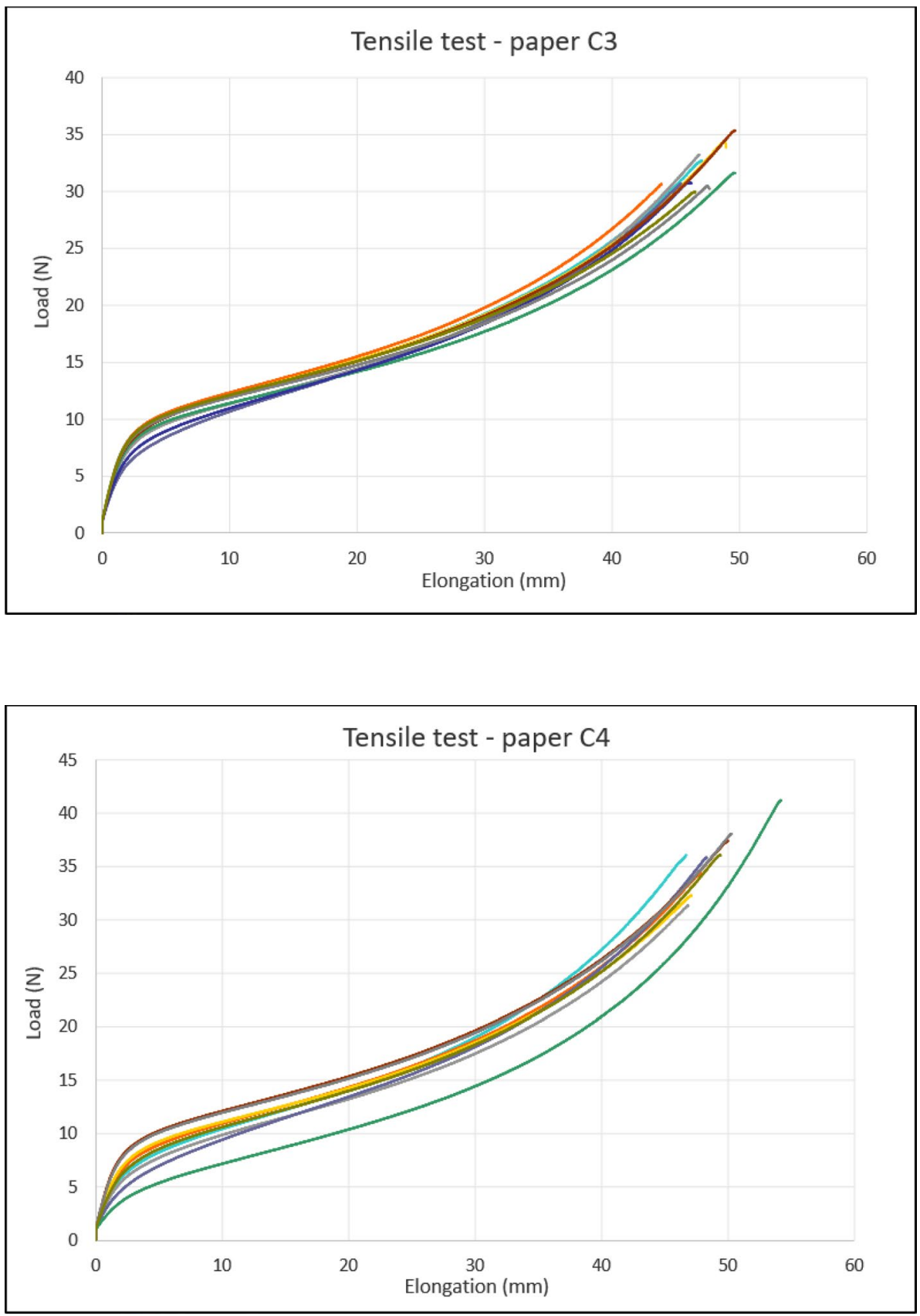
Fig. 30 Force elongation curves of individual specimen of paper $\mathrm{C} 5$

Fig. 31 Force elongation curves of individual specimen of paper D1
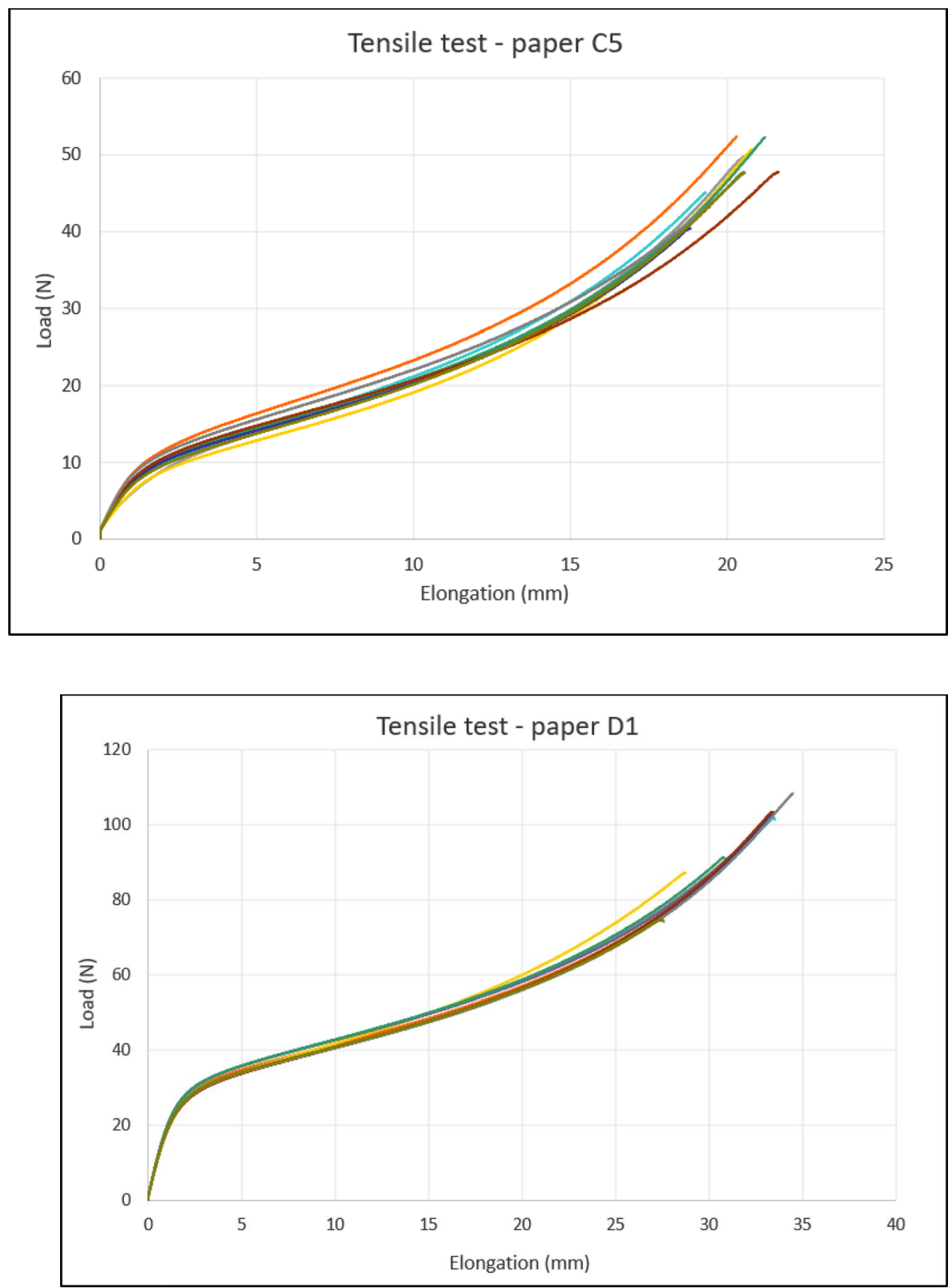
Fig. 32 Force elongation curves of individual specimen of paper D2

Fig. 33 Force elongation curves of individual specimen of paper D3
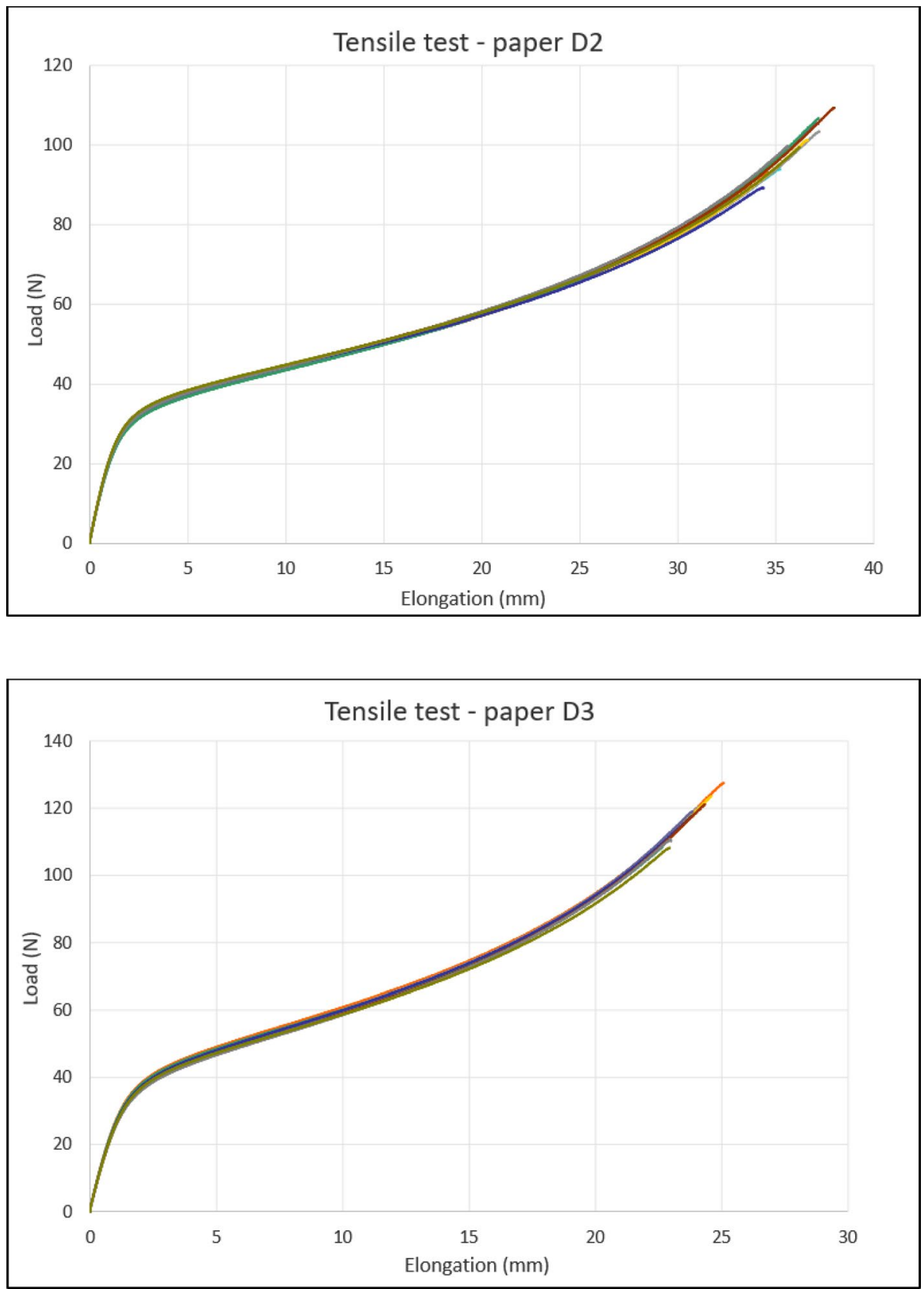
Fig. 34 Force elongation curves of individual specimen of paper D4

Fig. 35 Force elongation curves of individual specimen of paper D5
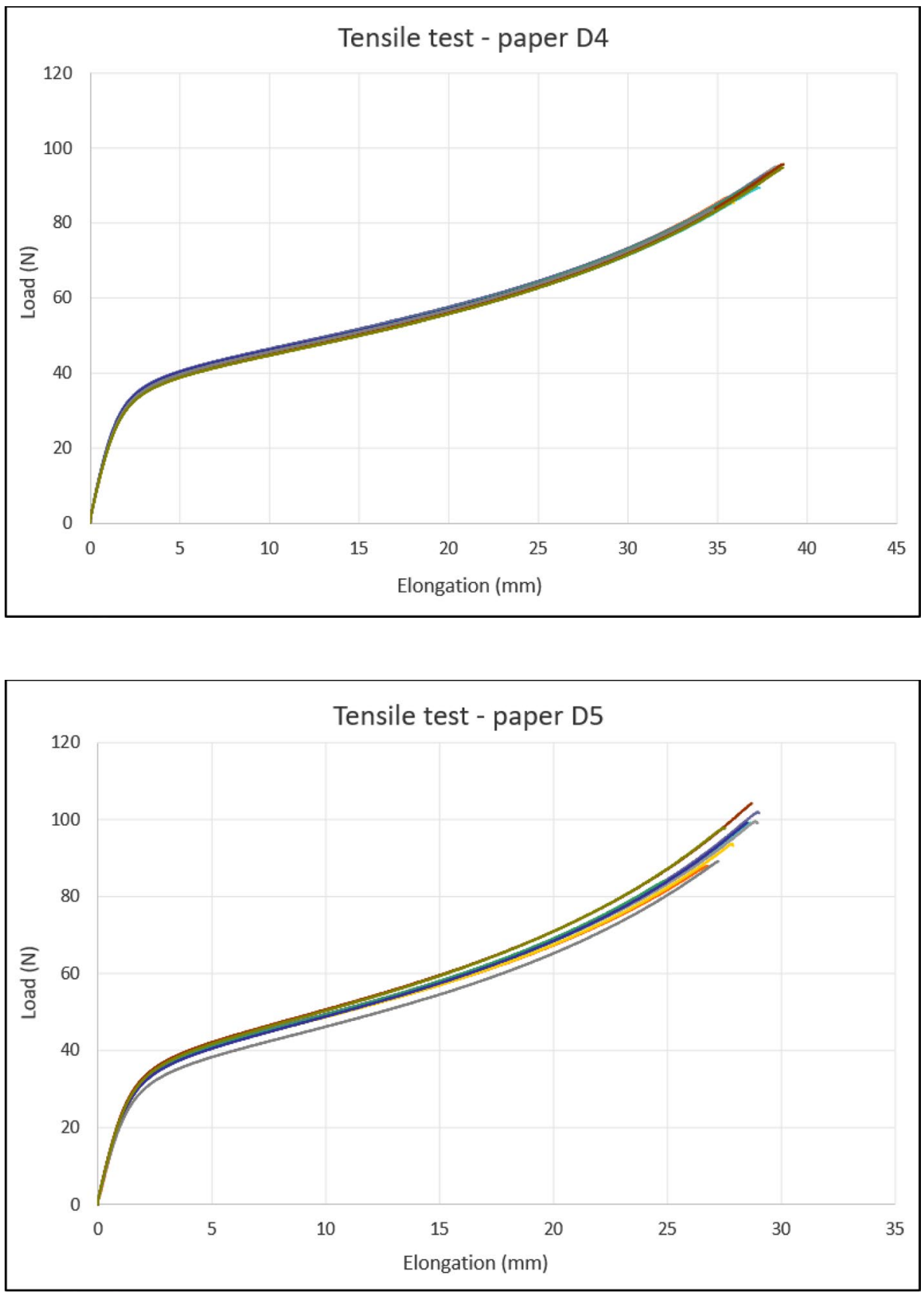
Fig. 36 Force elongation curves of individual specimen of paper $E$
Fig. 37 Force elongation curves of individual specimen of paper $F$
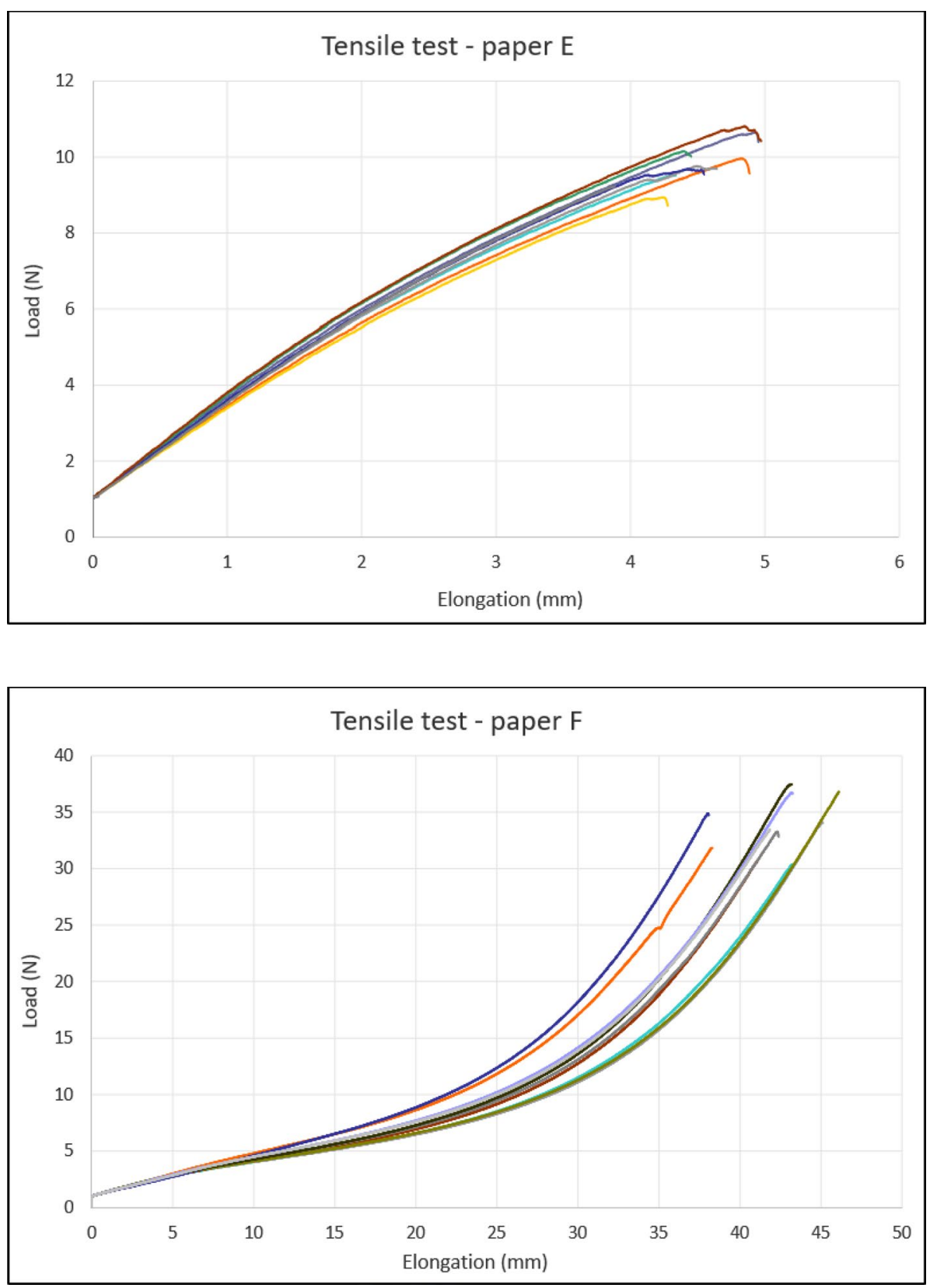
Fig. 38 Force elongation curves of individual specimen of paper $G$

Fig. 39 Force elongation curves of individual specimen of paper $\mathrm{H}$
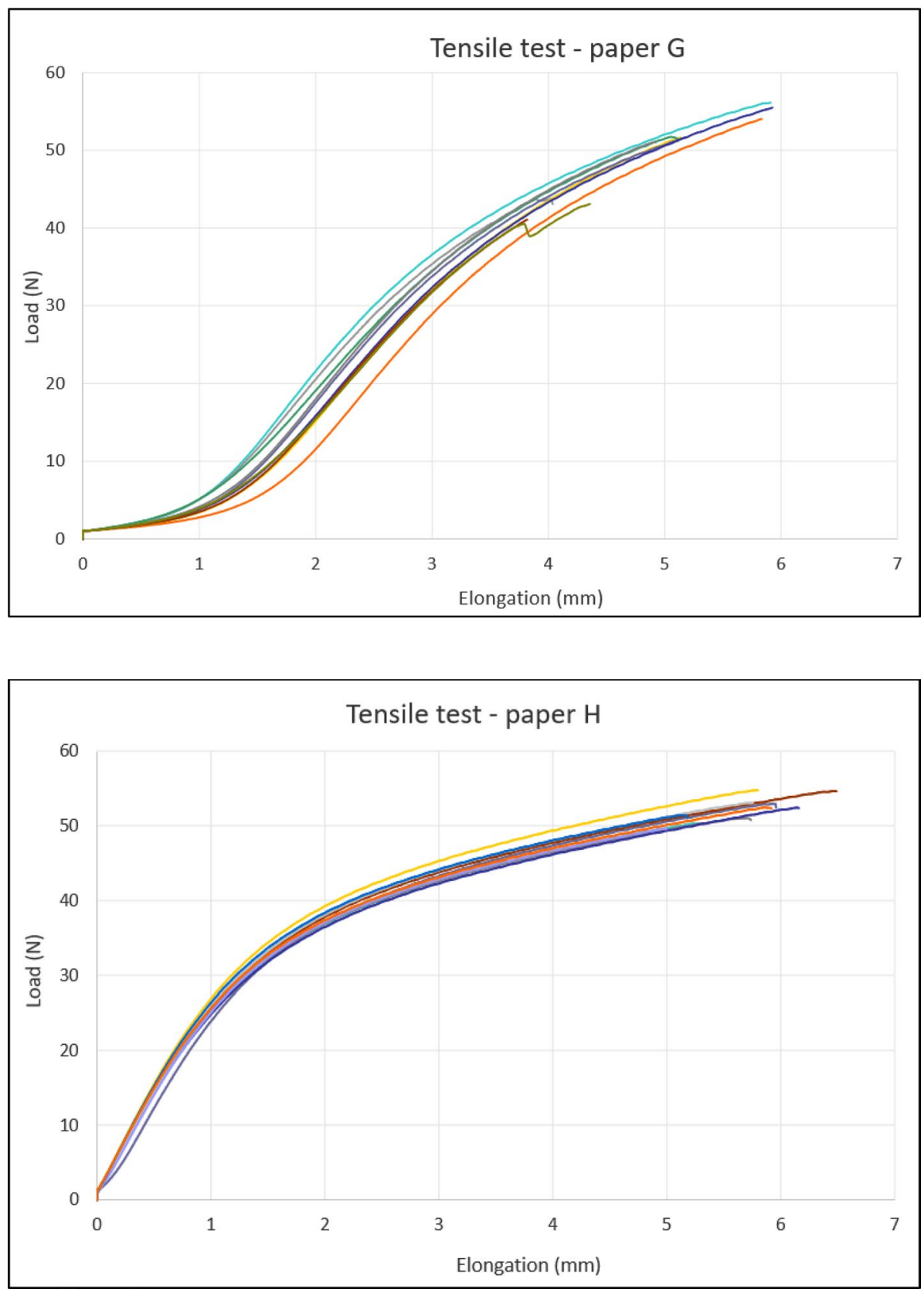
Fig. 40 Force elongation curves of individual specimen of paper I
Fig. 41 Force elongation curves of individual specimen of paper $\mathrm{P}$
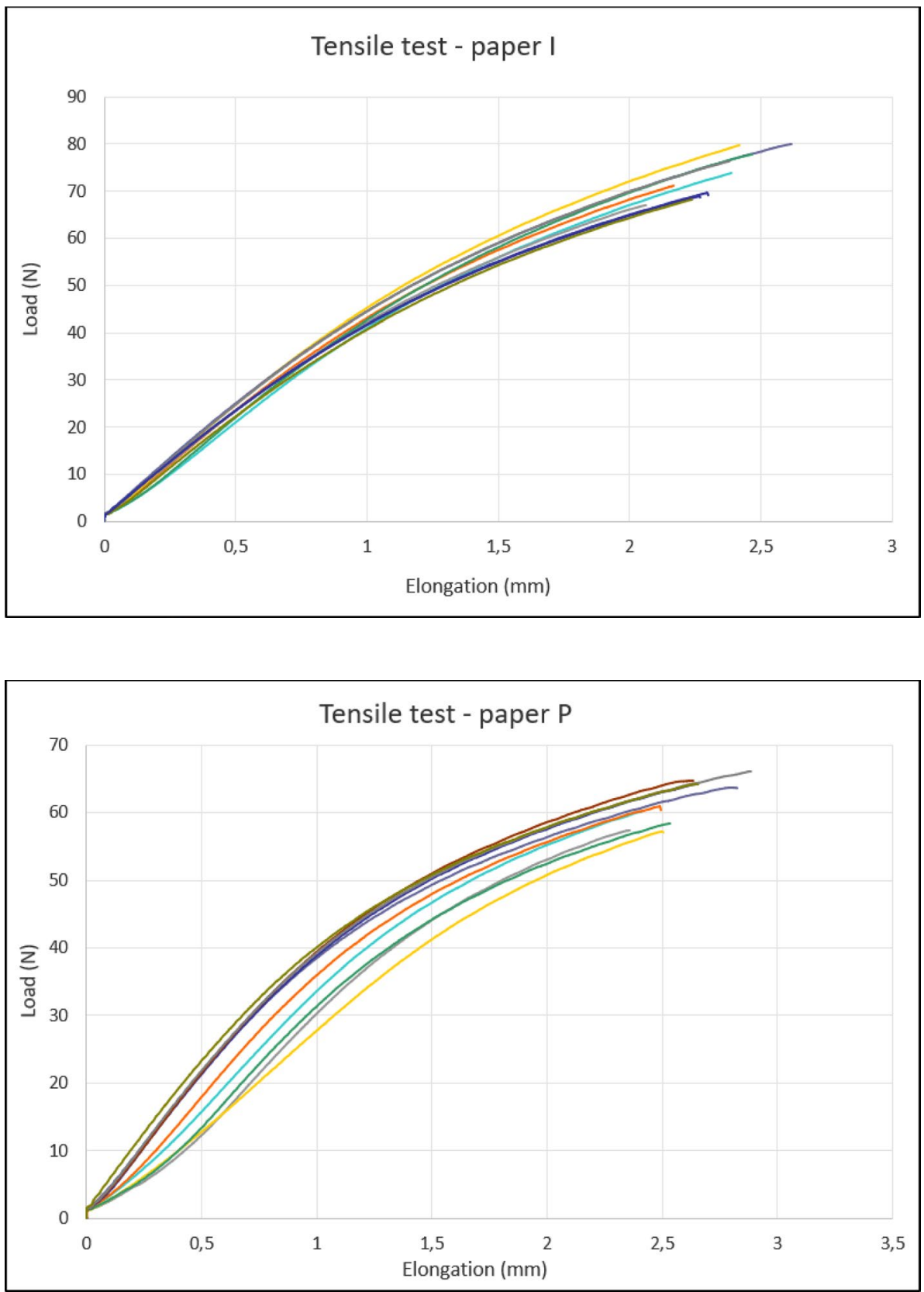

\section{References}

1. Wang L, Chen A-J (2012) The damage boundary curve of the suspension packaging system under rectangular pulse. Appl Mech Mater 105-107:70-73

2. Juwet M, Vanden BG, Esprit E (2018) On horizontal dynamic effects on palletized goods during road transport. Packag Technol Sci 30(5):310-330

3. Nica W., Juwet M. (2019) Transport safety of E-commerce packaging. www.ami.international, (01-07). Presented at the AMI stretch and shrink film conference, Barcelona, April 2019

4. Böröcz $P$ (2019) Vibration and acceleration levels of multimodal container shipping physical environment. Packag Technol Sci 32:269-277. https://doi.org/10.1002/pts.2434
5. Böröcz P, Singh S (2018) Measurement and analysis of delivery van vibration levels to simulate package testing for parcel delivery in Hungary. Packag Technol Sci 31:342-352. https://doi.org/ 10.1002/pts.2327

6. Zhou H, Wang Z-W (2018) Measurement and analysis of vibration levels for express logistics transportation in South China. Packag Technol Sci 31:665-678. https://doi.org/10.1002/pts. 2404

7. Singh S, Joneson E, Singh J, Grewal G (2008) Dynamic analysis of less-than-truckload shipments and test method to simulate this environment. Packag Technol Sci 21:453-466. https://doi. org/10.1002/pts.787

8. Greco A, Renzini A, Vaccari M, De Camargo FV (2019) Testing methods and equipment for palletized products. IOP Conf Ser: Mater Sci Eng 659:012087 
9. Papagrigoraki A., Leberle U. (2015) Best Available Technique (BAT) Conclusions for the Production of Pulp, Paper and Board. (Cepi conference) Retrieved from https://www.cepi. org/best-available-technique-bat-conclusions-for-the-produ ction-of-pulp-paper-and-board/

10. Presas T., Mensink M. (2011) The Forest Fibre Industry, 2050 Roadmap to a low-carbon bio-economy. (Cepi conference) Retrieved from http://apki.net/wp-content/uploads/2012/06/ The-Forest-Fibre-Industry-2050-Roadmap-to-a-Low-CarbonBio-economy.pdf

11. Berg P., Lingqvist O. (2019) Pulp, paper, and packaging in the next decade: Transformational change. (McKinsey) Retrieved from https://www.mckinsey.com/industries/paper-forest-produ cts-and-packaging/our-insights/pulp-paper-and-packaging-inthe-next-decade-transformational-change

12. Toppinen, A., Pätäri, S., Tuppura, A., \& Jantunen, A. (2017). The European pulp and paper industry in transition to a bio-economy a Delphi study. Futures: The Journal of Policy Planning and Futures Studies, 88, 1-14. https://doi.org/10.1016/j.futures.2017. 02.002

13. EUR-Lex. (n.d.). EU directive $2018 / 852$ of the European Parliament and of the Council of May 30, 2018 on packaging and packaging waste. Retrieved from https://eur-lex.europa.eu/ legal-content/EN/TXT/?uri=celex:32018L0852

14. EUR-Lex. (n.d.). EU directive 2019/904 of the European Parliament and of the Council of June 5, 2019 on the reduction of the impact of certain plastic products on the environment. Retrieved from https://eur-lex.europa.eu/eli/dir/2019/904/oj

15. Eurostat. (10, December 2020). Packaging waste statistics. https://ec.europa.eu/eurostat/statistics-explained/index.php/ Packaging_waste_statistics

16. Roman J, Nica W, Chalmet R, Juwet M (2019) (2020) Towards automated packaging for e-commerce logistics. Malays $\mathrm{E}$ Commer J (MECJ) 3(3):27-30. https://doi.org/10.26480/mecj.03.2019. 27.30

17. Borodulina S, Kulachenko A, Galland S, Nygards M (2012) Stressstrain curve of paper revisited. Nord Pulp Pap Res J 27:318. https://doi.org/10.3183/NPPRJ-2012-27-02-p318-328

18. Larsson T, Lindström T, Carlsson L, Fellers C (2018) Fiber length and bonding effects on tensile strength and thoughness of kraft paper. J Mater Sci 53:3006-3015. https://doi.org/10.1007/ s10853-017-1683-4

19. Linvill $\mathrm{E}$, Ostlund $\mathrm{S}$ (2014) The combined effects of moisture and temperature on the mechanical response of paper. Exp Mech 54:1329-1341. https://doi.org/10.1007/s11340-014-9898-7

20. Coffin DW (2005) The creep response of paper. Adv Paper Sci. https://doi.org/10.15376/frc.2005.2.651

21. Fadiji T, Corné CJ, Opara UL (2020) Evaluating the displacement field of paperboard packages subjected to compression loading using digital image correlation (DIC). Food Bioprod Proc 123:60-71. https://doi.org/10.1016/j.fbp.2020.06.008

22. Wang Z-W, Sun Y-C (2018) Experimental investigation on bending fatigue failure of corrugated paperboard. Packag Technol Sci 31:601-609. https://doi.org/10.1002/pts.2390

23. Hauptmann M, Majschak J-P (2011) New quality level of packaging components from paperboard through technology improvement in 3D forming. Packag Technol Sci 24(7):419-432. https://doi.org/10.1002/pts.941

24. Lahti J, Schmied F, Bauer W (2014) A method for preparing extensible paper on the laboratory scale. Nord Pulp Pap Res J 29:317321. https://doi.org/10.3183/NPPRJ-2014-29-02-p317-321

25. Khakalo, A., Kouko, J., Retulainen, E., \& Rojas, O. J. (2018) Superstretchable paper-based materials for 3D forming. Finland VVD. Dresden.
26. Fellers C, Bäckström M, Htun M, Lindholm G (1998) Paper-topaper friction-Paper structure and moisture. Nord Pulp Pap Res J 13(3):225-232

27. Lamb M, Rouillard V, Milverton J (2019) An evaluation of the mechanical performance of extruded wheat starch loose fill. Packag Technol Sci 32:511-521. https://doi.org/10.1002/pts. 2465

28. Profili J, Asadollahi S, Vinchon P, Dorris A, Beck S, Sarkassian A, Stafford L (2020) Recent progress on organosilicon coatings deposited on bleached unrefined Kraft paper by non-thermal plasma process at atmospheric pressure. Prog Org Coat 147:105865. https://doi.org/10.1016/j.porgcoat.2020.105865

29. Barbier C, Larsson P-L, Östlund S (2005) On dynamic effects at folding of coated papers. Compos Struct 67:395-402

30. Akter T, Nayeem J, Quadery AH, Razzaq MA, Uddin MT, Bashar MS, Jahan MS (2020) Microcrystalline cellulose reinforced chitosan coating on kraft paper. Cellul Chem Technol 54(1-2):95-102

31. Amir S, van de Ven T (2018) Colloidal starch and cellulose nanocrystals unite to improve the mechanical properties of paper: from enhanced coatings to reinforced nanocomposites. ACS Appl Nano Mater 1(4):1841-1852. https://doi.org/10.1021/ acsanm.8b00251

32. Hong S-I, Han J, Krochta J (2004) Optical and surface properties of whey protein isolate coatings on plastic films as influenced by substrate, protein concentration, and plasticizer type. J Appl Polym Sci 92:335-343

33. Jankovic-Castvan I, Lazarevic S, Stojanovic D, Zivkovic P, Petrovic $R$, Janackovic $D$ (2015) Improvement of the mechanical properties of paper by starch coatings modified with sepiolite nanoparticles. Starch/stärke 380(67):373. https://doi.org/10.1002/ star.201400171

34. Khwaldia K (2010) Water vapor barrier and mechanical properties of paper-sodium caseinate and paper-sodium caseinateparaffin wax films. J Food Biochem 34:998-1013. https://doi.org/ 10.1111/j.1745-4514.2010.00345.x

35. Khwaldia K, Arab-Tehrany E, Desobry S (2010) Biopolymer coatings on paper packaging materials. Compr Rev Food Sci Food Saf 9:82-91

36. Khwaldia K, Banon S, Perez C, Desobry S (2004) Properties of sodium caseinate film-forming dispersions and films. J Dairy Sci 87(7):2011-2016

37. Reis AB, Yoshida CM, Reis AC, Franco TT (2011) Application of chitosan emulsion as a coating on Kraft paper. Polym Int 60:963969. https://doi.org/10.1002/pi.3023

38. Shankar S, Rhim J-W (2018) Juli 20) Effects of poly(butylene adipate-co-terephthalate) coating on the water resistant, mechanical, and antibacterial properties of Kraft paper. Prog Org Coat 123:153-159. https://doi.org/10.1016/j.porgcoat.2018.07.002

39. Wang S, Jing Y (2016) Effects of a chitosan coating layer on the surface properties and barrier properties of kraft paper. BioResources 11(1):1868-1881

40. Lenske $A$, Müller T, Penter L, Schneider $M$, Hauptmann $M$, Majschak J-P (2017) Evaluating the factors influencing the friction behavior of paperboard during the deep drawing process. BioResources 12(4):8340-8358

41. Hofmann A, Wallmeier M, Hautpmann M, Majschak J-P (2019) Characterization of the material elongation in the deep drawing of paperboard. Packag Technol Sci 32(6):287-296. https://doi. org/10.1002/pts.2436

42. Tanninen, P., Matthews, S., Ovaska, S.-S., Varis, J., \& Backfolk, K. (2017). A novel technique for the evaluation of paperboard performance in press-forming. Journal of Material Processing Technology, 240(C), 284-292. https://doi.org/10.1016/j.jmatp rotec.2016.10.002 
43. Müller T, Lenske A, Hauptmann M, Majschak J-P (2017) Analysis of dominant process parameters in deep drawing of paperboard. BioResources 12(2):3530-3545. https://doi.org/10.15376/ biores.12.2.3530-3545

44. Vishtal A, Retulainen E (2012) Deep-drawing of paper and paperboard: the role of material properties. BioResources 7(3):4424-4450

45. Gurav S, Bereznitski A, Heidweiller A, Kandachar P (2003) Mechanical properties of paper-pulp packaging. Compos Sci Technol 63:1325-1335

46. Kouko J, Turpeinen T, Kulachenko A, Hirn U, Retulainen E (2020) Understanding extensibility of paper: role of fiber elongation and fiber bonding. Tappi J 19(3):125-135. https://doi.org/10. 32964/TJ19.3.125

47. Huang $H$, Nygards $M$ (2010) A simplified material model for finite element analysis of paperboard creasing. Nordic Pulp Paper Res J 25(4):505-512. https://doi.org/10.3183/ NPPRJ-2010-25-04-p505-512

48. ISO 1924-2:2008 Paper and board - Determination of tensile properties, edition 3 , ISO/TC6/SC2

Publisher's Note Springer Nature remains neutral with regard to jurisdictional claims in published maps and institutional affiliations. 